\title{
Contributions of the Optic Tectum and the Retina as Sources of Brain-Derived Neurotrophic Factor for Retinal Ganglion Cells in the Chick Embryo
}

\author{
Karl-Heinz Herzog ${ }^{1}$ and Christopher S. von Bartheld ${ }^{2}$ \\ ${ }^{1}$ Department of Neurobiochemistry, Max-Planck-Institut for Psychiatry, D-82152 Martinsried, Germany, and ${ }^{2}$ Department \\ of Physiology and Cell Biology, University of Nevada School of Medicine, Reno, Nevada 89557
}

Retinal ganglion cells (RGC) are supported by brain-derived neurotrophic factor (BDNF), but it is not known if BDNF acts as a target-derived factor or as an afferent or autocrine trophic factor. Here we demonstrate that BDNF mRNA is expressed in the retinorecipient layer of the chick optic tectum as well as in the inner nuclear layer and ganglion cell layer of the retina. Amacrine cells rather than RGC were the main source of BDNF mRNA in the ganglion cell layer, as determined by in situ hybridization that was combined with retrograde labeling of RGC and destruction of RGC by optic stalk transection, followed by quantitative RT-PCR. Cells in the ganglion cell layer as well as the retinorecipient layers of the optic tectum were BDNF-immunolabeled. After injections into the tectum, radioiodinated BDNF was transported to the retina where autoradiographic label accumulated in the inner plexiform and ganglion cell layers. After intraocular injection, iodinated BDNF accumu- lated in these same retinal layers and correlated with the distribution of p75 neurotrophin receptor protein. The majority of cross-linked receptor-bound BDNF in the retina immunoprecipitated with $\mathrm{p} 75$ antibodies. No difference in the intensity of BDNF immunolabel was observed in the experimental retina or tectum after optic stalk transection, indicating that most of the BDNF in the RGC was not derived from the optic tectum. These data indicate that a substantial fraction of the BDNF in the ganglion cell layer is derived from local sources, afferents within the retina, rather than from the optic tectum via retrograde transport.

Key words: retina; neurotrophin; BDNF; visual system; development; optic tectum; in situ hybridization; retinal ganglion cell; chick embryo; immunocytochemistry; neurotrophin receptor; retrograde transport; amacrine cell
During neurogenesis an excess number of neurons is produced, which subsequently is eliminated by naturally occurring cell death. According to the neurotrophic hypothesis, neurons require target-derived trophic signals for their maintenance and survival (for review, see Purves, 1988; Oppenheim, 1991). However, afferents also provide trophic support to developing neurons, and this form of anterograde afferent trophism is thought to be equally important to retrograde trophism (Oppenheim, 1991; Linden, 1994).

The retinotectal system presents a particularly advantageous system for the discrimination of target-derived (retrograde) and local (autocrine or paracrine) sources of neurotrophins. Most retinal ganglion cells (RGC) degenerate after target removal or optic stalk transection in chicken (Hughes and LaVelle, 1975; Vanselow et al., 1990). RGC can be maintained by brain-derived neurotrophic factor (BDNF) in vitro (Johnson et al., 1986;

\footnotetext{
Received April 21, 1997; revised Jan. 21, 1998; accepted Feb. 3, 1998.

This study was supported by the Max Planck Society (K.-H.H.) and National Institutes of Health Grants HD 29177 and NS 35931 (C.S.v.B.). We thank P. Maisonpierre and G. D. Yancopoulos for chicken BDNF DNA; R. M. Lindsay for neurotrophins; S. Jungbluth, K. Bailey, and Y.-A. Barde for purified BDNF antibody; K. Bailey and Y.-A. Barde for a chick BDNF clone; H. Tanaka for p75 antibody; L. F. Reichardt, F. Lefcort, and D. O. Clary for trk antibodies; Y.-A. Barde, M. Bothwell, and E. F. Wheeler for logistic support; L. C. Schecterson for subcloning; E. F. Wheeler, B. Fritzsch, and E. C. Gunther for advice; and P. G. H. Clarke and D. O. Frost for comments.

Correspondence should be addressed to Dr. Christopher von Bartheld, Department of Physiology and Cell Biology, Anderson Medical Building-352, University of Nevada School of Medicine, Reno, NV 89557.

Dr. Herzog's present address: Department of Developmental Neurobiology, St. Jude Children's Research Hospital, Memphis, TN 38105.

Copyright (C) 1998 Society for Neuroscience $0270-6474 / 98 / 182891-16 \$ 05.00 / 0$
}

Rodríguez-Tébar et al., 1989; Cohen-Cory and Fraser, 1994), and cells in the RGC layer express the BDNF receptor trkB (Okazawa et al., 1993, 1995; Perez and Caminos, 1995; Rickman and Brecha, 1995; Cohen-Cory et al., 1996; Garner et al., 1996; Hallböök et al., 1996). The expression of BDNF mRNA in target regions and its upregulation by physiological input further support the view that BDNF derived from the target plays a role in the maintenance of RGC (Castrén et al., 1992; Cohen-Cory and Fraser, 1994; Herzog and Barde, 1994; Herzog et al., 1994; Schoups et al., 1995) (for review, see von Bartheld, 1998a), but the retrograde transport of $\mathrm{BDNF}$ from the tectum to the retina has not been shown in the developing visual system.

Besides the target, local sources also provide trophic support to RGC (de Araujo and Linden, 1993; Linden, 1994; AryPires et al., 1997), yet the factor or factors involved have not been identified. One strong candidate is BDNF (Cohen-Cory et al., 1996). The expression of BDNF mRNA in the tectum (Leibrock et al., 1989) as well as in the retina (Cohen-Cory and Fraser, 1994; Herzog et al., 1994) allowed us to explore the respective contributions of the target and local sources of the same trophic factor. It is important to distinguish between different sources of trophic support (axon terminus vs dendrite/soma) because of their potential distinct trophic effects (Clarke, 1985; McAllister et al., 1995) and, in the case of RGC, clinical implications for the delivery of trophic factors after injury.

Here we demonstrate which cell layers express BDNF mRNA in the retina and optic tectum of chick embryos, where the BDNF protein is transported and accumulates after retrograde transport, and which receptors bind BDNF in the retina. We also 
demonstrate that RGC contain significant amounts of BDNF that are derived predominantly from cells within the retina. These data support the notion that local retinal sources provide a considerable amount of the BDNF for RGC and that RGC may use BDNF derived from cells within the retina in a paracrine manner.

\section{MATERIALS AND METHODS}

Animals. Fertilized White Leghorn chicken eggs were obtained from local suppliers and were incubated in humidified incubators at $37.5-38^{\circ} \mathrm{C}$. Approximately 1800 chicken eggs were used. The ages of chick embryos were verified at the time of death according to the method of Hamburger and Hamilton (1951). Experimental procedures were conducted in compliance with the Policy on the Use of Animals in Neuroscience Research and were approved by the local animal care committee.

In situ hybridization. A chicken BDNF cDNA (Maisonpierre et al., 1992) (courtesy of P. Maisonpierre and G. Yancopoulos, Regeneron, Tarrytown, NY) was subcloned into pGEM. Single-stranded riboprobes (527 bp) were labeled with ${ }^{35}$ S-uridine $5^{\prime}$-triphosphate (UTP) and used for hybridization as described (von Bartheld et al., 1991). To improve the sensitivity of the hybridization, we labeled another riboprobe (530 bp of the coding region; courtesy of K. Bailey, Martinsried, Germany) with ${ }^{33} \mathrm{P}$-UTP. Cryosections were used for the ${ }^{33} \mathrm{P}$-hybridizations, whereas paraffin sections were used for the ${ }^{35}$ S-hybridizations. Cryosections (12 $\mu \mathrm{m}$ ) were treated with $0.0005 \%$ Proteinase K (Boehringer Mannheim, Indianapolis, IN) for $8 \mathrm{~min}$, followed by an acetylation step with acetic anhydride in $0.1 \mathrm{~m}$ triethanolamine, $\mathrm{pH} 8$, for $10 \mathrm{~min}$. After dehydration, sections were hybridized with ${ }^{33} \mathrm{P}$-labeled riboprobes $\left(10^{7} \mathrm{cpm} / \mu \mathrm{l}\right)$ overnight. Subsequently, sections were washed in $2 \times$ SSC for $15 \mathrm{~min}$, followed by treatment with RNase $(100 \mathrm{mg} / \mathrm{ml}$; Boehringer Mannheim) for $30 \mathrm{~min}$ at $37^{\circ} \mathrm{C}$. After sections were rinsed in RNase buffer $(0.5 \mathrm{M} \mathrm{NaCl}$, $10 \mathrm{~mm}$ Tris- $\mathrm{HCl}$, and $1 \mathrm{~mm}$ EDTA, $\mathrm{pH} 8$ ), slides were incubated at $60^{\circ} \mathrm{C}$ in $2 \times \mathrm{SSC}$ for $1 \mathrm{hr}$, followed by a stringency wash in $0.2 \times$ SSC. Sections were dehydrated, coated in NTB-2 emulsion (Kodak, Rochester, NY), exposed, and developed after 2 weeks.

Animals of embryonic days E13 and E15/16 were anesthetized and perfused with $4 \%$ paraformaldehyde (PFA). Some of these embryos had undergone an optic stalk transection at E4 as described below, whereas others received an intraocular injection of BDNF or vehicle at E15 as described below. Whole heads or eyes and brains were dehydrated, cryosectioned $(12 \mu \mathrm{m})$ or embedded in paraffin, and sectioned at $10 \mu \mathrm{m}$. Sections through the brain and retina were collected on Silane-coated glass slides, together with sections through the otocysts from 4-d-old chick embryos. These sections served as positive controls because otocysts express high levels of BDNF mRNA (Hallböök et al., 1993). Adjacent sections were hybridized with sense control probes. Hybridization conditions were as described previously (von Bartheld et al., 1991). Sections were exposed for 14-28 d, developed, and lightly counterstained with thionine. Brain structures were identified according to Kuenzel and Masson (1988) and tectal layers according to the criteria of LaVail and Cowan (1971).

Retrograde labeling combined with in situ hybridization. Several approaches were used to double-label RGC, including the application of a tracer to the cut optic nerve in vitro (Fritzsch and Hallböök, 1996) and the in vivo injection into the optic tectum of the retrograde tracers fluorescein-horseradish peroxidase, horseradish peroxidase-DAPA (Sigma, St. Louis, MO), or the lysine-fixable $3000 \mathrm{MW}$ dextran simultaneously labeled with biotin and tetramethylrhodamine (Microruby, Molecular Probes, Eugene, OR). The Microruby injections proved to be the most successful. Approximately $1 \mu \mathrm{l}$ of a $0.1 \mathrm{mg} / \mu \mathrm{l}$ Microruby solution was injected into the optic tectum of 14-d-old chick embryos with microfine "insulin" disposable syringes. The embryos were anesthetized 18 hr later and perfusion-fixed with 4\% PFA; the age of the embryos (E14-E15) was verified (Hamburger and Hamilton, 1951). The brains were dissected, and those with a suitable injection site were cryoprotected in $4 \%$ PFA containing $15 \%$ sucrose at $4^{\circ} \mathrm{C}$. After $4 \mathrm{hr}$, the brains were frozen in OCT compound and sectioned at $20 \mu \mathrm{m}$ to map the injection site in the tectum and to assess the extent of retrograde labeling in the optic tract. The eyes of animals with suitable penetration of the tracer were processed for in situ hybridization as described above, except that some sections were not hybridized to evaluate the amount of quenching. Sections were not dehydrated and cleared in xylene but were coverslipped in aqueous mounting medium (Vectashield, Vector Laboratories, Burlingame, CA). Sections were analyzed and photographed via epifluorescence with rhodamine filters, dark field or bright field, and the percentages of fluorescent and nonfluorescent cells were determined as well as the percentages of cells labeled for BDNF mRNA ( $\geq 3$ grains/cell body). Quantitative analyses were performed on six visual fields of sections through the retina in which the fluorescent labeling and the in situ hybridization showed normal labeling intensities and patterns. The centralmost retina and the peripheral retina were excluded from this analysis, because the ratios of RGC and amacrine cells are more extreme in these regions (Ehrlich, 1981). A total of 392 cells was evaluated; statistical significance was determined by unpaired Student's $t$ test.

Quantification by RT-PCR. Quantification of BDNF mRNA was performed as detailed elsewhere (Herzog et al., 1994). In brief, an in vitro transcript of the coding sequence bearing one nucleotide exchange was added to the tissue when RNA was extracted. This nucleotide exchange in the recovery standard, after reverse transcription and PCR, led to a new restriction site recognized by BamHI. RNA was extracted by the cesium trifluoro-acetate (CsTFA) method at ages E17 and E14, and reverse transcription followed by PCR was performed in a one-tube reaction protocol. The PCR product was cleaved by Bam HI, separated on an $8 \%$ polyacrylamide gel, and electroblotted. PCR products were detected by a probe, and signals resulting from the recovery standard and the endogenous BDNF mRNA were compared with the aid of a laser densitometer.

Optic stalk transection. Fertilized White Leghorn chicken eggs were incubated in a humidified incubator, and, beginning with E3, embryos were cultured in Petri dishes (Auerbach et al., 1974) or windowed in ovo. At E4 the right optic stalk was transected just behind the eyeball with a pair of microscissors, and the embryo was allowed to develop until tissue preparation at E8.5, E11, E14/E15, or E17. Successful transections were verified by dissection of the region in which the optic chiasm normally forms, and tissues were processed for PCR, immunocytochemistry, or in situ hybridization only when the optic nerve was absent on the operated side.

Immunohistochemical methods. A rabbit serum was raised against the $\mathrm{N}$-terminal portion of mouse BDNF (His-Ser-Asp-Pro-Ala-Arg-ArgGly-Glu-Leu-Ser-Val-Cys) coupled to KLH. This serum was affinitypurified by the peptide coupled to Sepharose, as described elsewhere (Jungbluth et al., 1994). For controls the purified serum was incubated at a dilution of 1:200 in the presence of the BDNF peptide and the neurotrophin-3 (NT-3) peptide representing an NT-3 sequence (TyrAla-Glu-His-Lys-Ser-His-Arg-Gly-Glu-Tyr-Ser-Val-Cys) coupled to Sepharose beads, respectively, in $0.1 \%$ Triton X-100 in PBS. After $3 \mathrm{hr}$ at room temperature the beads were centrifuged for $10 \mathrm{~min}$ at $10,000 \times$ $g$, and the supernatant was processed directly for immunostaining.

After anesthesia with Nembutal, chicken embryos were perfused transcardially with 4\% PFA in PBS; tecta and retinae were post-fixed in the same fixative for $16 \mathrm{hr}$ at $4^{\circ} \mathrm{C}$. Some animals were perfused with high or low $\mathrm{pH}$ buffers before fixation (Zhou et al., 1994) to dissociate BDNF from its receptors and to determine whether this may enhance antibodyantigen interaction and improve the immunolabeling. As this was not the case, animals were perfused routinely with neutral $\mathrm{pH}$ buffers. After sucrose impregnation of the tissues $\left(30 \%\right.$ sucrose for $24 \mathrm{hr}$ at $\left.4^{\circ} \mathrm{C}\right), 12 \mu \mathrm{m}$ cryosections were thawed on gelatin-coated slides. Some sections through the tectum were cut at $30 \mu \mathrm{m}$, and free-floating sections were processed. Brain sections were cut in the transverse plane. Immunostaining was performed according to the Vector protocol (Vector Laboratories) with some modifications. In brief, some sections were treated with three washes of $50 \%$ ethanol and then were incubated with diluted blocking serum for $30 \mathrm{~min}$ at room temperature, followed by three washes with PBS and $0.1 \%$ Triton X-100 (PBT) and incubation overnight with primary antisera diluted 1:200 in PBT in a humid chamber at $4^{\circ} \mathrm{C}$. Sections were rinsed three times and incubated with a biotinylated goat anti-rabbit antibody diluted in blocking serum. For immunostaining with monoclonal p75 antibody (Tanaka et al., 1989; von Bartheld et al., 1995), a biotinylated horse anti-mouse antibody was used. After three washes $\mathrm{ABC}$ reagent was applied to the sections for $30 \mathrm{~min}$, rinsed three times, and preincubated for $10 \mathrm{~min}$ in $0.1 \%$ diaminobenzidine (DAB) in $0.04 \%$

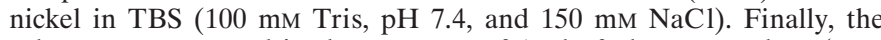
substrate was reacted in the presence of $1 \mu \mathrm{l}$ of glucose oxydase (type $\mathrm{V}-\mathrm{S}$, Sigma) in $1 \mathrm{ml}$ of $0.1 \%$ DAB, $0.04 \%$ nickel, and glucose in TBS until the reaction product was clearly visible. Slides were rinsed in water, dehydrated, and coverslipped.

Injections of radio-iodinated BDNF. Human recombinant BDNF was obtained from Regeneron (courtesy of Dr. Ronald Lindsay, Regeneron). BDNF was iodinated by using a modification (von Bartheld, 1998b) of 
the method of Vale and Shooter (1985). Iodinated BDNF migrated on SDS gels as a single band at $\sim 14 \mathrm{kDa}$, was transported in a receptormediated manner, and retained $86 \%$ of its activity in a dorsal root ganglion cell assay (von Bartheld et al., 1996b). Injections into the tectum were made as described previously for injections into the vitreous (von Bartheld et al., 1994). Approximately 1-2 $\mu$ l of iodinated BDNF was injected with microfine disposable syringes (Becton Dickinson, Franklin Lakes, NJ) in embryos at E8 $(n=2), \mathrm{E} 13 / \mathrm{E} 14(n=5)$, and E17/E18 $(n=$ $6)$. After $20 \mathrm{hr}$ of survival, the animals were anesthetized and perfused transcardially with 4\% PFA. The amount of radioactivity in the dissected midbrains (E14 and E18) or whole heads (E9) was measured in a gamma counter (cpm were $\sim 50,000-150,000$ for E9 and E14, and 200,000300,000 for E18). The brains and the eyes were embedded in paraffin, and a series of 1 in 15 sections $(10 \mu \mathrm{m}$ thickness $)$ through the brain was collected on glass slides and exposed on x-ray film for 2-5d; the sections were coated with NTB-2 emulsion. The ipsilateral and contralateral retinae were sectioned at $10 \mu \mathrm{m}$, and a 1 in 15 series of sections was collected on three sets of slides and coated with NTB-2 emulsion. Sections were exposed for 10-21 d (brains) or 3-8 weeks (retinae) at $4^{\circ} \mathrm{C}$. Slides were lightly counterstained with thionine after development and were coverslipped. After injections of iodinated proteins into the retina or into the tectum, the amount of radioactivity in the eyes was measured in a gamma counter. Autoradiographic silver grains were counted over retinal layers by using 40 or $100 \times$ objectives, and grain profiles were plotted from at least 10 counts (averages). These were compared with grain counts from control retinae.

Cross-linking of BDNF and immunoprecipitation of BDNF receptors in the retina. ${ }^{125} \mathrm{I}$-labeled $\mathrm{BDNF}(20-30 \mathrm{ng})$ was injected into the eye at E15. Animals were anesthetized $20 \mathrm{hr}$ later with Nembutal and perfused with PBS; the retinae were dissected and placed in cold lysis buffer (50 mM HEPES or Tris-Cl and 1\% NP-40 or Triton X-100) containing $1 \mathrm{~mm}$ phenyl-methyl sulfonylfluoride, $1 \mu \mathrm{g} / \mathrm{ml}$ aprotinin, $1 \mu \mathrm{g} / \mathrm{ml}$ leupeptin, and one of two cross-linkers, either 1-ethyl-3(3dimethylaminopropyl)carbodiimide-HCl (EDC; Pierce, Rockford, IL) or disuccinimidyl suberate (DSS; Pierce) at a final concentration of $6 \mathrm{~mm}$ (EDC) or $0.1 \mathrm{~mm}$ (DSS). The tissue was triturated by being drawn through 22-G needles and spun; the supernatant was incubated at room temperature for $30 \mathrm{~min}$, followed by $30 \mathrm{~min}$ at $4^{\circ} \mathrm{C}$ with $50 \mathrm{~mm}$ L-lysine. Quadruplicate or duplicate samples of $100 \mu \mathrm{l}$ were nutated for 1-24 $\mathrm{hr}$ at $4^{\circ} \mathrm{C}$ with antibodies $(1 \mu \mathrm{g} / 100 \mu \mathrm{l})$ specific for the extracellular domain of chicken p75 (ChEX; Weskamp and Reichardt, 1991), chicken trkB (von Bartheld et al., 1996b), chicken trkC (Lefcort et al., 1996), or normal rabbit IgG as a control for nonspecific precipitation. A washed Pansorbin cell suspension (10 $\mu$; Calbiochem, San Diego, CA) was added, nutated for an additional $1 \mathrm{hr}$ at $4^{\circ} \mathrm{C}$, and centrifuged for $10 \mathrm{~min}$. The radioactivity was counted separately for the pellets and the supernatants, and the specific precipitation was determined by subtraction of the counts in the nonspecific $\operatorname{IgG}$ pellet. Specific precipitation was up to $\sim 20 \%$ of total counts. The total percentage of receptor-bound BDNF and the relative contributions of the three different receptors were calculated. In parallel sets of control experiments the cross-linker was omitted to test the efficiencies of cross-linking.

Control experiments to compare the precipitation efficiencies of the antibod$i e s$. To determine whether the efficiencies with which the antibodies immunoprecipitated the neurotrophin receptors were approximately similar for p75 and trkB, we cross-linked and immunoprecipitated ${ }^{125}$ I-labeled BDNF, which was bound to Sepharose-protein A beads (CL-4B, Pharmacia Biotech, Piscataway, NJ). Samples were loaded on 6\% SDS PAGE and blotted onto nitrocellulose (SS-NC, Schleicher \& Schuell, Keene, NH). Some blots were probed with p75 or trkB antibodies and detected with horseradish peroxidase-conjugated secondary antibodies and an enhanced chemiluminescent substrate (SuperSignal CL-HRP Substrate System, Pierce). Other blots were probed directly with ${ }^{125}$ I-labeled p75 or trkB antibodies $[10 \times$ $10^{6} \mathrm{cpm} / \mathrm{ml}$, according to Hockfield et al. (1993)] and radio-iodinated with lactoperoxidase after the preparation of Fab fragments (Harlow and Lane, 1988). Blots were exposed to film, and the resulting bands at 75 and 140 $\mathrm{kDa}$ were quantified by laser densitometry. ${ }^{125}$ I-labeled blots generally rendered cleaner background, but bands visualized with chemiluminescence gave essentially the same results.

\section{RESULTS}

\section{BDNF mRNA expression in the optic tectum}

Previous studies showed that similar amounts of BDNF mRNA are expressed in the retina and tectum during the period of

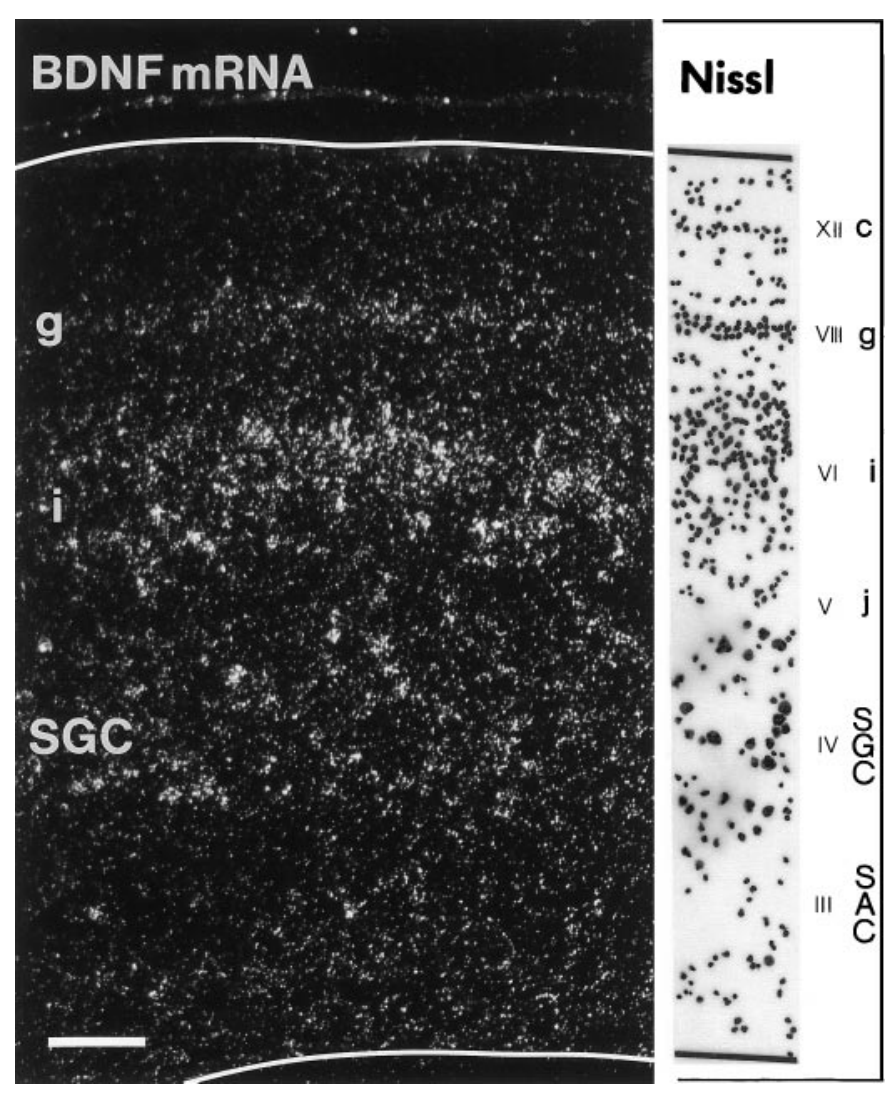

Figure 1. Expression of BDNF mRNA in the optic tectum of a chick embryo at $15.5 \mathrm{~d}$ of incubation (E15.5). Dark-field view of a transverse section through the central region of the tectum hybridized with a ${ }^{35} \mathrm{~S}$ labeled riboprobe for chicken BDNF. BDNF mRNA-expressing layers and the corresponding Nissl staining of the same section (camera lucida tracing) are indicated on the right [embryonic layers $I I I-V I, V I I I$, and XII, according to LaVail and Cowan (1971)]. Note that the expression of BDNF is most intense in the deeper half of layer SGFSi. SGFS sublayers $c, g, i$, and $j$ are indicated. $S G C$, Stratum griseum centrale; $S A C$, stratum album centrale. Scale bar, $100 \mu \mathrm{m}$.

developmental cell death of RGC (Herzog et al., 1994). Using in situ hybridization, we examined the localization of BDNF transcripts at E13-E16 when RGC are dependent on their target (Hughes and LaVelle, 1975; Nurcombe and Bennett, 1981). BDNF mRNA was expressed in the retinorecipient layers stratum griseum et fibrosum superficiale (SGFS) and stratum griseum centrale (SGC) of the optic tectum. The most abundant expression was seen at E15-E16 in the sublayer SGFSi and g (layers VI and VIII, respectively, of the embryonic tectum) (LaVail and Cowan, 1971) and the SGC (layer IV). Most of the labeled cells in SGFSi were located in the central parts, but not in the more superficial or the deepest parts of this lamina (Fig. 1). Many cells were labeled heavily with 6-12 grains per cell body, and it was evident in several labeled cells that most of the silver grains were clustered at the transition zone between the cell body and the apical dendrite (Fig. 2). The apical dendrites of most neurons in layer SGFSi extend into the superficial layers (mainly SGFSa-f; LaVail and Cowan, 1971; Hunt and Brecha, 1984; von Bartheld, unpublished data), where they are contacted by RGC axons (Crossland et al., 1975). Neurons in the SGFSg layer were labeled distinctly, but with a lower intensity than those in SGFSi or SGC. Although many cells in SGFSi and g appeared to express BDNF mRNA, labeling in SGC was more heterogeneous, with some 


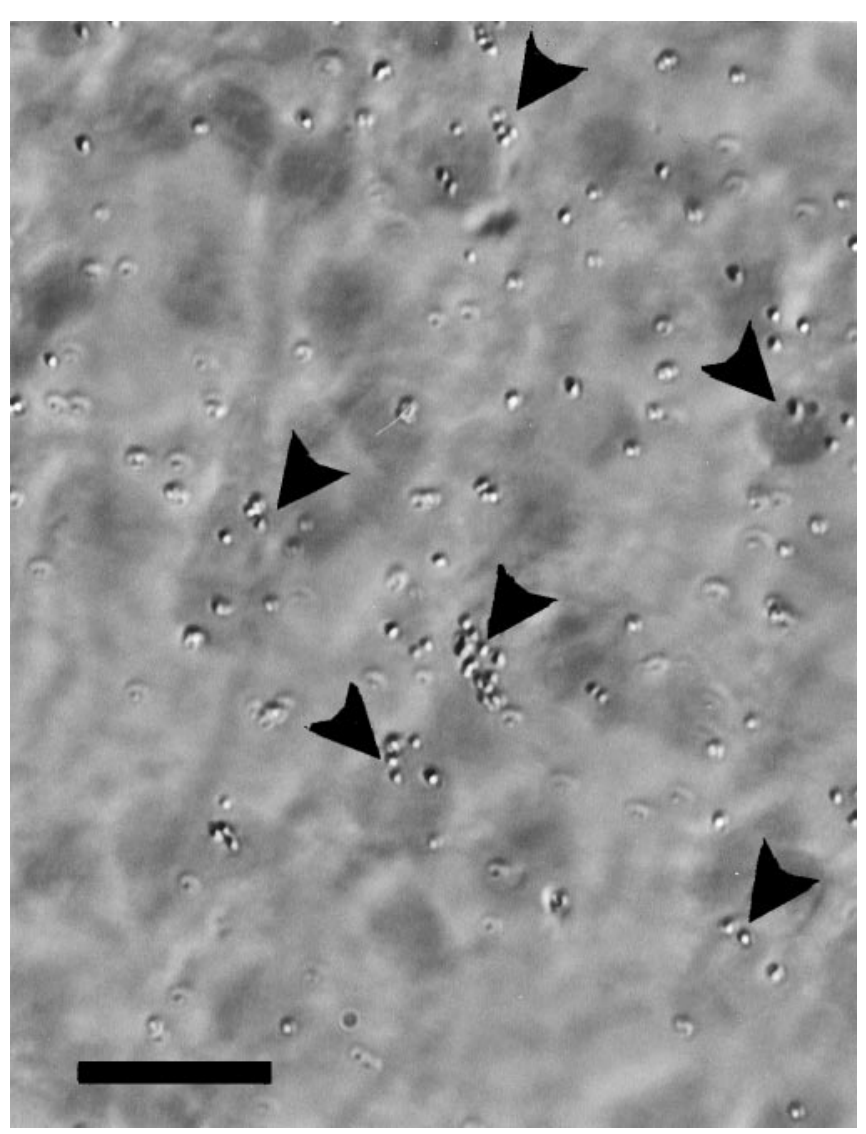

Figure 2. BDNF mRNA expression in neurons of tectal layer SGFSi at E15.5. Note that silver grains $\left({ }^{35} \mathrm{~S}\right.$-labeled $)$ frequently accumulate over the apical half of the soma (arrowheads) from which the apical dendrite extends into the retinorecipient layers. The pial surface of the tectum is toward the top of the micrograph. Scale bar, $10 \mu \mathrm{m}$.

neurons expressing high levels and some expressing very low levels of BDNF (Fig. 1). Only a subpopulation of avian SGC neurons receive direct $\mathrm{RGC}$ input via their apical dendrites (Hardy et al., 1985). BDNF mRNA could be detected in 15$25 \%$ of large neurons in the SGC, and there was no preferred subcellular localization of silver grains in these multipolar neurons. BDNF transcripts were not detected in other visual nuclei in the brain, e.g., the lateral geniculate nucleus or the nucleus of the basal optic root (nucleus ectomamillaris). BDNF mRNA was observed readily in several nonvisual nuclei and ganglia, including the hippocampus, the area hippocampalis, the nucleus inferioris hypothalami, the nucleus nervi glossopharyngei et nucleus motorius dorsalis nervi vagi, and the trigeminal ganglion (data not shown). In summary, these data indicate that neurons in several layers of the tectum may release BDNF from their dendrites in layers SGFSa-f and thus may provide BDNF for RGC axons. When E15 embryos received an injection of $200 \mathrm{ng}$ of BDNF or vehicle only in one eye, there was no obvious difference in the intensity of hybridization between the ipsilateral and the contralateral tectum 20-24 hr later.

\section{BDNF mRNA expression in the retina}

In the E15-E16 retina, BDNF mRNA was distributed over several layers. With ${ }^{35} \mathrm{~S}$-labeled probes, discretely higher grain densities were seen over the ganglion cell layer (GCL) and the inner border of the inner nuclear layer (INL; data not shown). The ${ }^{33} \mathrm{P}$-labeled series was more sensitive than the ${ }^{35} \mathrm{~S}$-labeled series because label over individual cell bodies could be identified. A small fraction (5-10\%) of cells in the GCL was labeled for BDNF mRNA (Fig. $3 A$ ). The frequency of labeled cells (as a percentage of the entire GCL population) appeared to be higher in the peripheral retina than in the central retina (data not shown). The GCL contains RGC as well as a substantial number of displaced amacrine cells (approximately one-third of the cells in the GCL) (Ehrlich, 1981; Layer and Vollmer, 1982). As described below, most of the labeled cells in the GCL are displaced amacrine cells. BDNF expression was seen occasionally in cells of the inner INL (data not shown) and was strong over the outer half of the INL (Fig. 3B,C), which contains the cell bodies of horizontal cells and bipolar cells. Hybridization also was seen over the ONL, as in the E18 retina (Hallböök et al., 1996). When embryos received an injection of $200 \mathrm{ng}$ of BDNF or vehicle in the eye at E15, the expression of BDNF mRNA in the GCL was increased in the injected eye after 20-24 hr, consistent with previous reports (Ballarin et al., 1991; Mansour-Robaey et al., 1994).

Because BDNF mRNA was expressed in layers of the retina containing RGC, we examined the possibility that BDNF was expressed by RGC and thus may support themselves in an autocrine manner (Acheson et al., 1995; Cohen-Cory et al., 1996; Gao et al., 1997). RGC were retrogradely labeled by injections of Microruby into the optic tectum in vivo, and the sections subsequently were hybridized for BDNF mRNA. Microruby labeled many cells in the GCL $(\sim 70 \%$, Fig. $4 A, B)$, consistent with the percentage of RGC within the chicken GCL (Ehrlich, 1981). In situ hybridization did not quench the signal (Fig. 4B), confirming a previous report (Fritzsch and Hallböök, 1996). The percentages of fluorescent and nonfluorescent cells in the GCL were determined as well as the percentages of cells labeled for BDNF mRNA (Fig. 4C, Table 1). The quantitative analysis showed that only a small percentage $(<3 \%)$ of fluorescent cells expressed BDNF mRNA, whereas a substantial fraction $(\approx 15 \%)$ of the unlabeled (presumed amacrine cells) in the GCL expressed BDNF mRNA (Fig. 4C, Table 1). These data provide direct evidence that most of the BDNF mRNA in the GCL is expressed by a subpopulation of amacrine cells, and not by RGC. If BDNF mRNA expression in the GCL were altered as a result of damage of RGC axons and terminals in the tectum when Microruby was injected, this should have taken a longer time $(>18 \mathrm{hr}$ ) for manifestation and likely would increase BDNF mRNA in the RGC rather than in the amacrine cells (Gao et al., 1997).

Nevertheless, to confirm that RGC do not express a major fraction of the BDNF mRNA in the retina, a second strategy was used: destruction of RGC and subsequent quantitative RT-PCR for BDNF mRNA in the eye. The optic stalk was transected at E4, before target innervation, which eliminated nearly all RGC at later stages of development (Vanselow et al., 1990). When levels of BDNF mRNA in the retinae were determined by quantitative RT-PCR and compared with age-matched normal retinae, BDNF mRNA levels were not reduced significantly (Fig. 4D). To rule out the possibility that amacrine or bipolar cells may upregulate BDNF expression in the absence of RGC, at E15 via in situ hybridization we examined sections from retinae transected at E4. There was no apparent difference in the pattern of BDNF expression in these retinae compared with the control side (see Fig. $3 C$ ) other than a reduced number of labeled cells in the GCL. This may represent the loss of a small fraction of BDNFexpressing RGC or the loss of, or BDNF downregulation within, a subpopulation of amacrine cells in the absence of RGC. There was no apparent increase in the labeling intensity over the INL, 


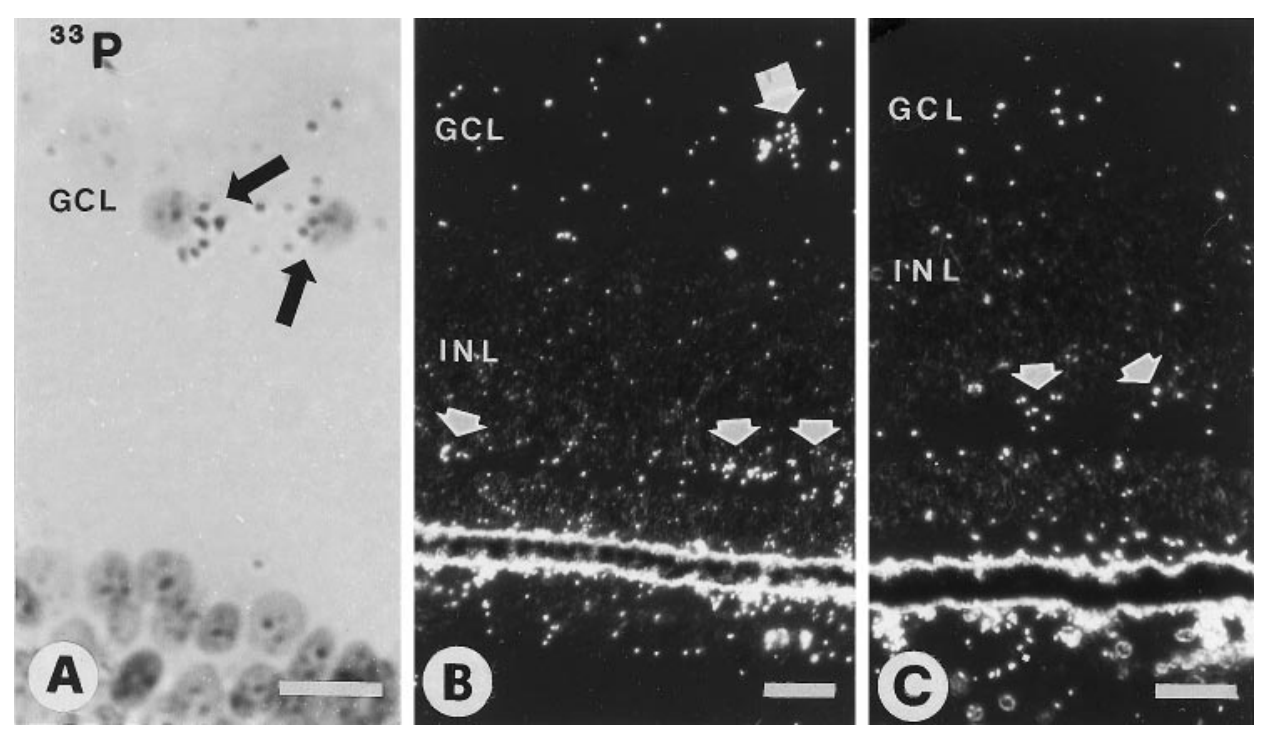

Figure 3. Retinae of E15 chick embryos hybridized with ${ }^{33} \mathrm{P}$-labeled riboprobes for chicken BDNF. $A$, Bright-field view of two labeled cells in the ganglion cell layer $(G C L$, arrows). $B$, Dark-field image of a labeled cell in the GCL (larger arrow) and several labeled cells in the outer half of the inner nuclear layer (INL, smaller arrows). C, Dark-field image of E15 retina after optic stalk transection at E4. Label in the outer half of the INL is maintained (arrows). Scale bars: $10 \mu \mathrm{m}$ in $A ; 20 \mu \mathrm{m}$ in $B, C$. which contains the bulk of the amacrine and all of the bipolar cells (see Fig. 3C). Taken together, these data demonstrate that the majority of BDNF in the retina is produced by cells other than RGC, probably by subpopulations of horizontal, bipolar, and amacrine cells, based on the in situ hybridization data.

\section{BDNF immunocytochemistry in the retina}

Expression of BDNF transcripts does not necessarily reflect a precise relationship between transcripts and translated protein (Nawa et al., 1995; Johnson et al., 1996), and the in situ hybridization does not allow us to evaluate which cells use and accumulate BDNF protein. To determine the localization of BDNF at the protein level, we used a previously characterized affinitypurified serum raised against a peptide (B6) of the N-terminal portion of BDNF. This antibody recognizes BDNF in Western blots (Jungbluth et al., 1994) and does not cross-react with NT-3. When this antibody was applied to the retinae of 8.5-d-old chick embryos, the GCL, but no other layer in the retina, was heavily labeled (Fig. 5A). To confirm further the specificity of the antibody, we incubated the serum in the presence of the B6 BDNF peptide coupled to Sepharose beads, and, after precipitation, sections of E8.5 retinae were incubated with the supernatant. No labeling was observed in the retinae in these control experiments (Fig. 5B). Immunolabeling also was abolished when the primary antibody was omitted. In contrast, preadsorption of the BDNF peptide serum against an NT-3 peptide resulted in labeling similar to the serum alone (data not shown). Therefore, we consider this antibody to be specific for BDNF.

BDNF-like immunoreactivity was detected at $\mathrm{E} 7$ in the retina (Fig. 6A); at this age all cells in the GCL were weakly labeled. At later stages (E8.5) BDNF labeling increased, and the intensity of labeled cells within the GCL became more heterogenous (Figs. $5 A, 6 F)$. A number of cell bodies in the GCL displayed strong labeling, whereas BDNF-like immunoreactivity was barely detectable in the neuropil [inner plexiform layer (IPL) and outer plexiform layer (OPL)]. Cells adjacent to the IPL, presumably amacrine cells, were labeled with much lower intensity. Furthermore, cells in proximity to the ora serrata were BDNF-positive (Fig. 6B). This cell population contains newly formed RGC, which presumably are not yet connected to the tectum (Rager, 1980). Neuronal processes in the OPL were labeled slightly above background. Naturally occurring cell death of RGC and cell death after target removal begins after E8.5 (Rager and Rager, 1978; Hughes and McLoon, 1979). When we compared retinae after optic stalk transection with controls at E8.5, no difference in the labeling of the INL or the GCL could be observed (compare Figs. $6 C, 5 A$ ). BDNF labeling at E11 was increased, and within the GCL most of the large-diameter neurons displayed strong immunoreactivity. Similar to the E8.5 retina, neurons adjacent to the IPL were labeled weakly at E11 (Fig. 6D). In the GCL of the normal E14 retinae the distribution of labeled cells was similar to that of the E11 eye. However, large neurons in the INL were labeled above background levels (data not shown). These neurons may represent displaced ganglion cells (Reiner et al., 1979). After optic stalk transection at E4, many cells in the GCL of the operated eye had disappeared at E14 (Fig. 6E). Only a few large-diameter neurons were BDNF-positive in the transected E14 GCL. These cells may produce their own BDNF, or they may acquire BDNF from neighboring amacrine cells.

\section{BDNF immunocytochemistry in the optic tectum}

Many neurons in the SGC and some neurons in the SGFS of the optic tectum were immunoreactive in the E15-E18 chick embryo (Fig. 7). Many of the labeled neurons in the SGC were large, with clearly labeled primary dendritic processes, but several small cells also were labeled in the SGC. Approximately $15-35 \%$ of all SGC neurons were lightly to moderately BDNF-labeled. In the SGFS, occasional neurons were labeled in the SGFSi and g. The labeled neurons in layer $\mathrm{i}$ were within the deeper third of this layer, whereas those in layer $g$ were slightly deeper than the more densely packed center of this sublayer. Although BDNF-labeled neurons in the SGFS were sparse in the normal animal, their frequency was increased substantially, especially in layer SGFSi, in embryos in which the contralateral eye had been manipulated by injecting either BDNF or vehicle solution. The effect of vehicle injections in the eye also may be attributable to BDNF, because such manipulations are known to increase the expression of endogenous neurotrophins, including BDNF, as described above (see also Ballarin et al., 1991; Mansour-Robaey et al., 1994). BDNF- or vehicle-injected animals showed an $\sim 10$-fold increased number of neurons that were immunolabeled clearly, and these were distributed over several sublayers of SGFS, predominantly sublayer i, but also b, c, e, g, h, and j. The size of labeled neurons in these layers differed, with relatively small neurons in b, c, and 

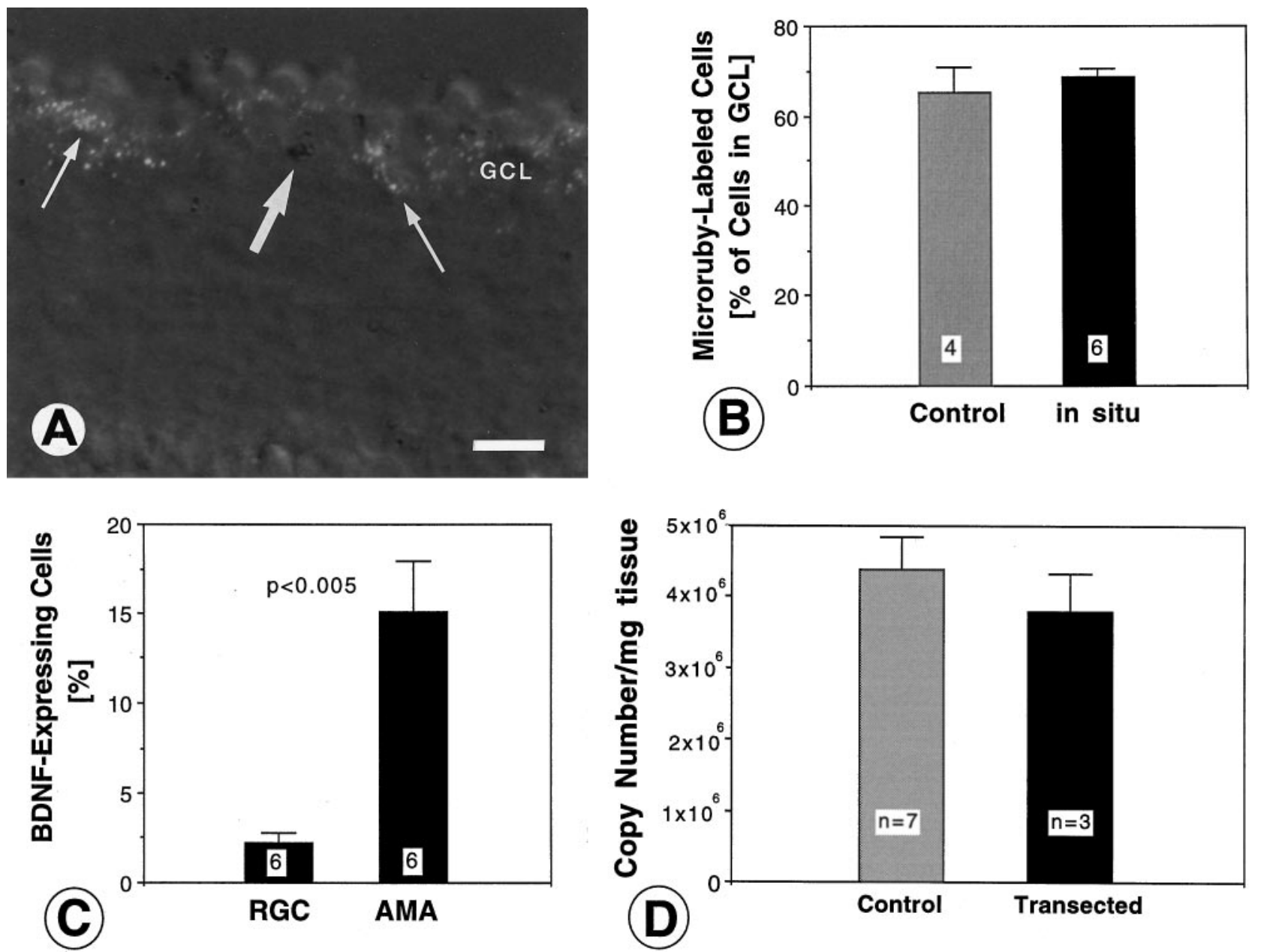

Figure 4. Identification and quantification of retinal ganglion cells $(R G C)$ and amacrine cells with BDNF expression in the ganglion cell layer $(G C L)$ of E15 chick embryos $(A-C)$ and quantification of BDNF mRNA in the retina after degeneration of $R G C$ induced by optic stalk transection ( $D$ ). $A$, Section through the retina retrogradely labeled with Microruby (white grains) and hybridized for BDNF mRNA (dark silver grains). Note that many RGC are retrogradely labeled (thin arrows), but most of the BDNF-expressing cells (large arrow) are not fluorescent. Not all Microruby grains are in the focus plane. Scale bar, $20 \mu \mathrm{m}$. B. Comparison of the percentage of Microruby-labeled cells $(R G C)$ in the $G C L$ before and after hybridization. Note that there is no apparent quenching of the fluorescent signal. The number of visual fields (with $\sim 70$ cells each) analyzed is indicated within white squares. Error bars indicate SEM. $C$, Percentages of BDNF-expressing cells for the RGC population (identified by labeling with Microruby) and for the amacrine cells ( $A M A$; identified by the lack of fluorescent label). Note that $<3 \%$ of RGC express BDNF, as compared with $\approx 15 \%$ of BDNF-expressing amacrine cells in the GCL. The number of visual fields analyzed (with a total of 392 cells) is indicated within white squares. Error bars indicate SEM. $D$, BDNF mRNA was measured at age E17 by quantitative RT-PCR in normal retinae (Control) and compared with retinae lacking most RGC (Transected). BDNF mRNA levels were not reduced significantly in retinae after the destruction of their RGC. Error bars indicate SEM. Similar data were obtained for retinae from age E14.

$\mathrm{j}$, and medium-sized neurons in layers e, g, and i. The labeled neurons in layer $i$ all had long apical dendrites that were labeled for $\sim 80 \mu \mathrm{m}$. In contrast to the SGFS layer, the frequency of BDNF-immunolabeled neurons did not appear to increase in layer SGC in the tectum of animals injected in the eye with vehicle or BDNF.

\section{Retrograde transport of BDNF from the tectum to the retina}

RGC from all species that were examined respond to BDNF in vitro (Johnson et al., 1986; Rodríguez-Tébar et al., 1989; CohenCory and Fraser, 1994), but it is not known if BDNF acts in vivo as a target-derived factor or as a local retinal factor. Neurons in the SGFSi and SGC layers of the tectum receive innervation from RGC axons (Crossland et al., 1975; Repérant and Angaut, 1977). BDNF mRNA is expressed in the optic tectum by neurons in layers that are known to receive retinal innervation, and RGC depend for survival on their target (Nurcombe and Bennett, 1981). Therefore, BDNF generally is assumed to be a retrograde trophic signal that is transported from the tectum to RGC (Cohen-Cory and Fraser, 1994). To determine whether BDNF can be transported retrogradely from the tectum to RGC, we radio-iodinated $\mathrm{BDNF}$, and $\sim 5 \mathrm{ng}$ was injected into the tectum of chick embryos of $8,13-14$, and $17-18 \mathrm{~d}$ of incubation. The transport of BDNF was examined by gamma counting of the radioactivity in the eyes (E13-E18) and by autoradiography of sections through the retinae (E8, E13-E18). Approximately 0.7$1.5 \mathrm{ng}$ of the injected BDNF remained in the midbrain at the time of death, as measured by gamma counting of the dissected midbrains. The successful injections typically were made in the dorsomedial tectum (Fig. $8 A$ ), and the injection site usually was restricted to $<5 \%$ of the entire tectum. Measurements of the radioactivity in the eyes showed $131.6 \%( \pm 8.81 \%$; SEM $)$ in 


\begin{tabular}{|c|c|c|c|c|c|c|c|c|}
\hline $\begin{array}{l}\text { Total } \\
\text { number/viewfield }\end{array}$ & $\begin{array}{l}\text { Microruby- } \\
\text { labeled (RGC) }\end{array}$ & Percentage & $\begin{array}{l}\text { Unlabeled } \\
\text { (AMA) }\end{array}$ & Percentage & $\begin{array}{l}\text { BDNF } \\
\text { mRNA }\end{array}$ & Percentage & $\begin{array}{l}\text { Double- } \\
\text { labeled }\end{array}$ & Percentage \\
\hline 56 & 36 & 64.3 & 20 & 35.7 & 5 & 8.9 & 1 & 1.8 \\
\hline 59 & 44 & 74.6 & 15 & 25.4 & 4 & 6.8 & 1 & 1.7 \\
\hline 64 & 45 & 70.3 & 19 & 29.7 & 4 & 6.3 & 0 & 0.0 \\
\hline 75 & 51 & 68.0 & 24 & 32.0 & 6 & 8.0 & 2 & 2.7 \\
\hline 63 & 46 & 73.0 & 17 & 27.0 & 2 & 3.2 & 1 & 1.6 \\
\hline 75 & 46 & 61.1 & 29 & 38.7 & 3 & 4.0 & 1 & 1.3 \\
\hline \multicolumn{9}{|l|}{ Total } \\
\hline 392 & 268 & & 124 & & 23 & & 6 & \\
\hline Average & & 68.6 & & 31.4 & & 6.2 & & 1.5 \\
\hline
\end{tabular}

RGC, Retinal ganglion cells; AMA, amacrine cells; BDNF mRNA-positive, $\geq 3$ grains/cell.
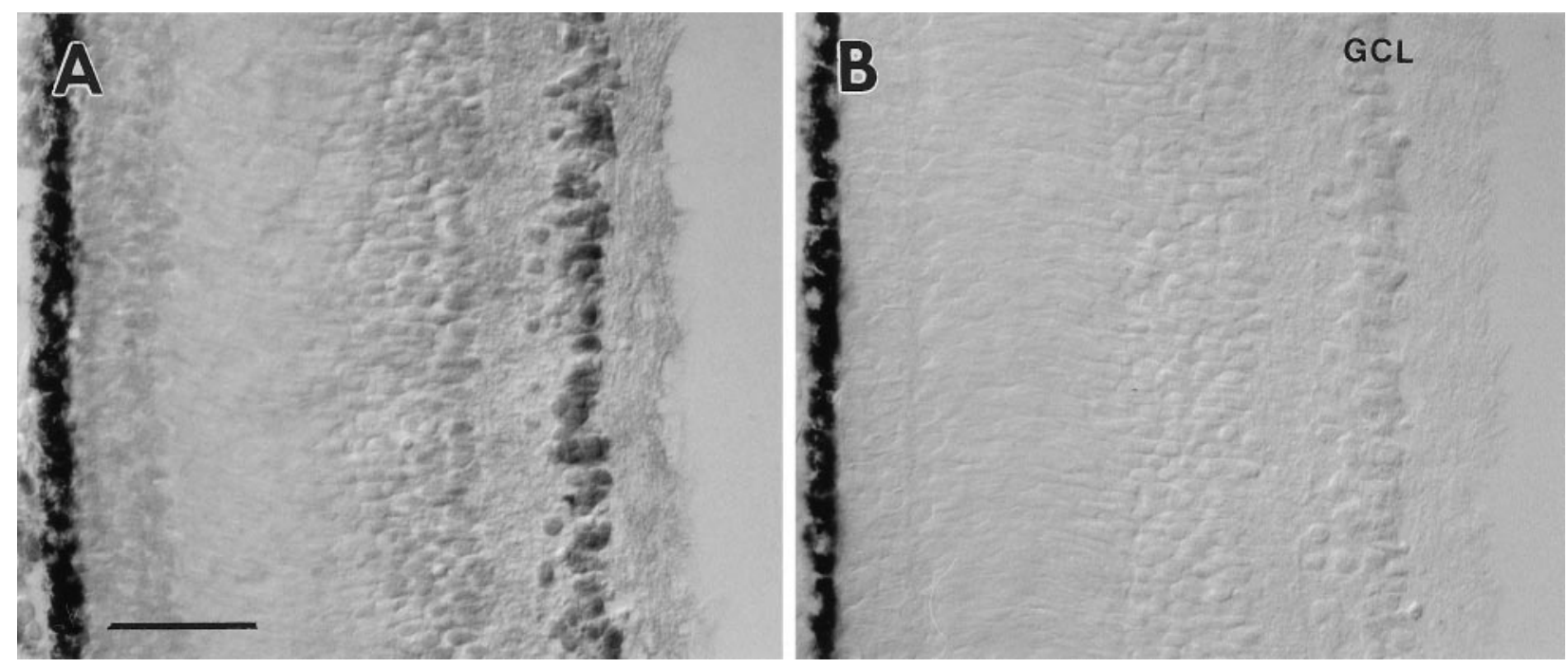

Figure 5. Specificity of the BDNF antiserum in tissue sections. $A$, The BDNF antiserum specifically recognizes cells in the ganglion cell layer (GCL) of an E8.5 retina. $B$, No label was detected in the $G C L$ after preincubation and precipitation of the serum with the B6 peptide coupled to Sepharose beads. Scale bar, $50 \mu \mathrm{m}$.

the contralateral eye when compared with the radioactivity in the ipsilateral eye $(=100 \%)$, indicating that the difference (equivalent to $\sim 0.3-0.5 \mathrm{pg}$ of BDNF) was transported specifically from the tectum to the retina. Specific transport was evident by emulsion autoradiography of sections through the retinae that accumulated iodinated BDNF exclusively in the IPL and GCL layers of the contralateral retina after tectal injections at E13/E14 and E17/E18 (Fig. 8B,C,E,F). No label was seen after injections at E8 (Fig. $8 D$ ). Label was seen only in the parts of the retina that are known to project to the region of the tectum containing the injection site. ${ }^{125}$ I-label was not seen by autoradiography in the ipsilateral retina, presumably because neurotrophins are degraded rapidly in the vascular system (Stöckel et al., 1976), and free ${ }^{125} \mathrm{I}$ is removed when the tissue is dehydrated (while the ${ }^{125} \mathrm{I}$ incorporated into neurotrophins remains within neurons). Profiles of the grain density over the different retinal layers were plotted from representative sections at ages E8, E14, and E18 (Fig. $8 D-F$ ). These profiles showed that most of the radioactivity $(>85 \%)$ accumulated over the IPL and that only $\sim 15 \%$ of the radioactivity was within the GCL. These data indicate that the tectum-derived BDNF accumulates predominantly in the dendrites of RGC rather than in their cell bodies. We cannot exclude the possibility that some of the radioactivity in the IPL represents degradation products of BDNF rather than intact protein. Label was not seen in the retinae at the earliest stage examined (E8), possibly because the density of retinal terminals in the tectum is too low at this age (Rager and von Oeynhausen, 1979; Thanos and Bonhoeffer, 1983).

The RGC are not the only afferent input to tectal neurons expressing BDNF. Several isthmic and diencephalic nuclei that innervate the SGC or SGFS depend on an intact retinotectal circuitry during development (Ostrach and Mathers, 1979; Wizenmann and Thanos, 1990; Clarke, 1992; Page et al., 1993), and many of them express the BDNF receptor trkB during development (Garner et al., 1996), including the relevant stages during the third week of incubation for the isthmo-optic nucleus (ION; von Bartheld et al., 1996b) and the parvocellular isthmic nucleus (Ipc; R. Williams, Karolinska Institute, personal communication). Therefore, BDNF produced by tectal neurons may be transported anterogradely or retrogradely and used by isthmic or thalamic nuclei. To examine if any of these nuclei may transport exogenous BDNF injected into the tectum, we collected sections through the brainstem, mesencephalon, and diencephalon and coated them with emulsion for autoradiography. Slightly increased grain density was observed over the ipsilateral Ipc, but not the ION, the magnocellular isthmic nucleus (Imc), or the 

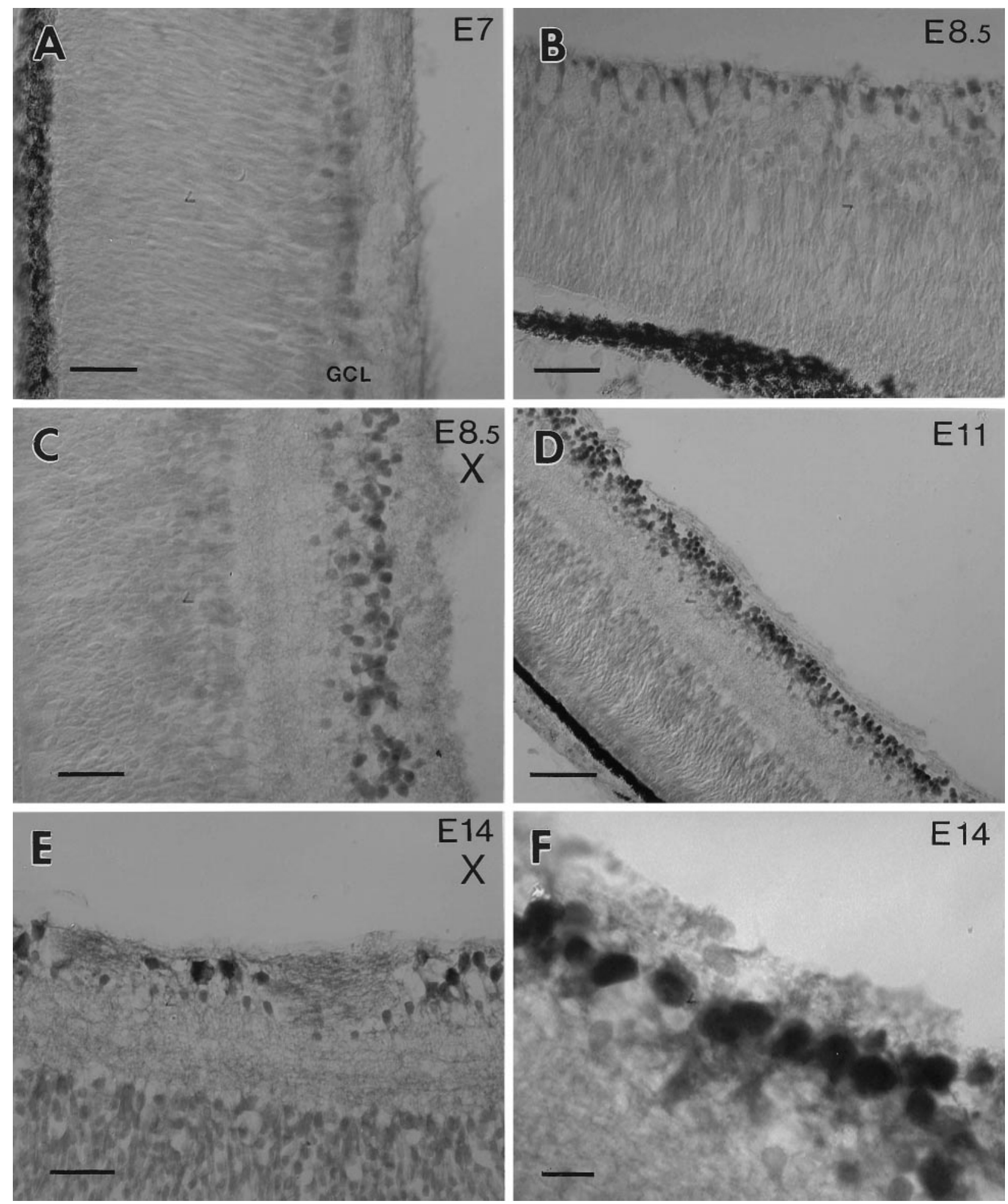

Figure 6. BDNF immunoreactivity in the retina. $A$, The ganglion cell layer $(G C L)$ of an $\mathrm{E} 7$ retina is weakly labeled. $B$, At E8.5 newly formed cells adjacent to the ora serrata are BDNF-positive. These cells presumably represent retinal ganglion cells (RGC). $C$, In an E.8.5 retina BDNF is not visibly reduced in the GCL after optic stalk transection $(X)$ at E4 (compare with Fig. 5A). $D$, At E11 many cells in the normal GCL are strongly labeled. $E$, After optic stalk transection $(X)$ many RGC have degenerated at E14. Some large cells display strong BDNF immunoreactivity. $F$, An E14 retina labeled with the BDNF antiserum at higher magnification displays heterogeneity of the label within the GCL. Scale bars: $25 \mu \mathrm{m}$ in $A-C, E ; 50 \mu \mathrm{m}$ in $D ; 10 \mu \mathrm{m}$ in $F$. 

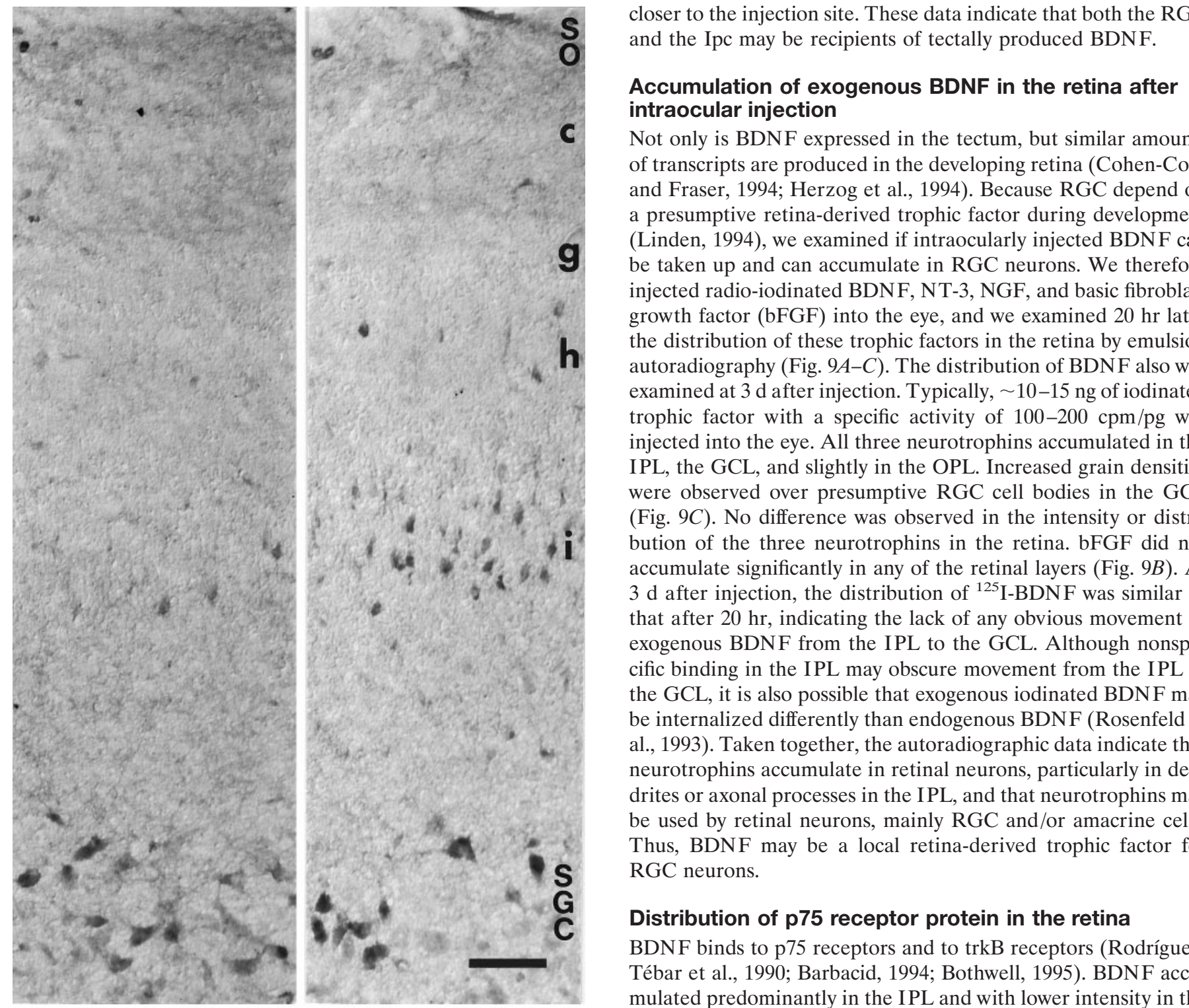

\section{after}

Not only is BDNF expressed in the tectum, but similar amounts of transcripts are produced in the developing retina (Cohen-Cory and Fraser, 1994; Herzog et al., 1994). Because RGC depend on a presumptive retina-derived trophic factor during development (Linden, 1994), we examined if intraocularly injected BDNF can be taken up and can accumulate in RGC neurons. We therefore injected radio-iodinated BDNF, NT-3, NGF, and basic fibroblast growth factor (bFGF) into the eye, and we examined $20 \mathrm{hr}$ later the distribution of these trophic factors in the retina by emulsion autoradiography (Fig. $9 A-C$ ). The distribution of BDNF also was examined at $3 \mathrm{~d}$ after injection. Typically, $\sim 10-15 \mathrm{ng}$ of iodinated trophic factor with a specific activity of $100-200 \mathrm{cpm} / \mathrm{pg}$ was injected into the eye. All three neurotrophins accumulated in the IPL, the GCL, and slightly in the OPL. Increased grain densities were observed over presumptive RGC cell bodies in the GCL (Fig. 9C). No difference was observed in the intensity or distribution of the three neurotrophins in the retina. bFGF did not accumulate significantly in any of the retinal layers (Fig. 9B). At $3 \mathrm{~d}$ after injection, the distribution of ${ }^{125}$ I-BDNF was similar to that after $20 \mathrm{hr}$, indicating the lack of any obvious movement of exogenous BDNF from the IPL to the GCL. Although nonspecific binding in the IPL may obscure movement from the IPL to the GCL, it is also possible that exogenous iodinated BDNF may be internalized differently than endogenous BDNF (Rosenfeld et al., 1993). Taken together, the autoradiographic data indicate that neurotrophins accumulate in retinal neurons, particularly in dendrites or axonal processes in the IPL, and that neurotrophins may be used by retinal neurons, mainly RGC and/or amacrine cells. Thus, BDNF may be a local retina-derived trophic factor for RGC neurons.

\section{Distribution of $\mathrm{p75}$ receptor protein in the retina}

$\mathrm{BDNF}$ binds to $\mathrm{p} 75$ receptors and to trkB receptors (RodríguezTébar et al., 1990; Barbacid, 1994; Bothwell, 1995). BDNF accumulated predominantly in the IPL and with lower intensity in the GCL. The chicken GCL (but not the IPL) contains full-length trkB protein (Okazawa et al., 1995; Cellerino and Kohler, 1997). Because all exogenously introduced neurotrophins accumulated in the same layer (IPL, Fig. 9C) despite the reported differential expression of members of the trk family of receptors in the chicken retina (Hallböök et al., 1996), we tested whether p75 was distributed in the same layer in which the exogenous BDNF accumulated. Immunocytochemistry with a monoclonal antibody to p75 (Tanaka et al., 1989; von Bartheld et al., 1995) showed distinct patterns of p75 label in the retina at E14-E16. Most neuropil label was in the IPL with punctate label, particularly in the outer third of the IPL (Fig. 10A). This distribution was very similar to the distribution pattern of exogenous BDNF. Two cell types were labeled in the INL. A very strong label was found in regularly spaced neurons at the inner margin of the INL ( $\sim 30-40 \mu \mathrm{m}$ apart), presumably representing a subpopulation of amacrine cells with labeled processes extending into the IPL (Fig. $10 A$ ). Another cell type was labeled with less intensity in the central parts of the INL and may represent bipolar cells and/or Müller glial cells (Fig. 10A). The OPL and possibly horizontal cells were labeled with low intensity in the central retina, but label

in the OPL was more intense in the peripheral retina (data not lateral spiriform nucleus either ipsi- or contralateral to the injection (data not shown). Label over the Ipc likely reflects true accumulation of transported BDNF rather than accumulation caused by diffusion from the injection site, because the Imc had a lower grain density than the Ipc, although the Imc is located 

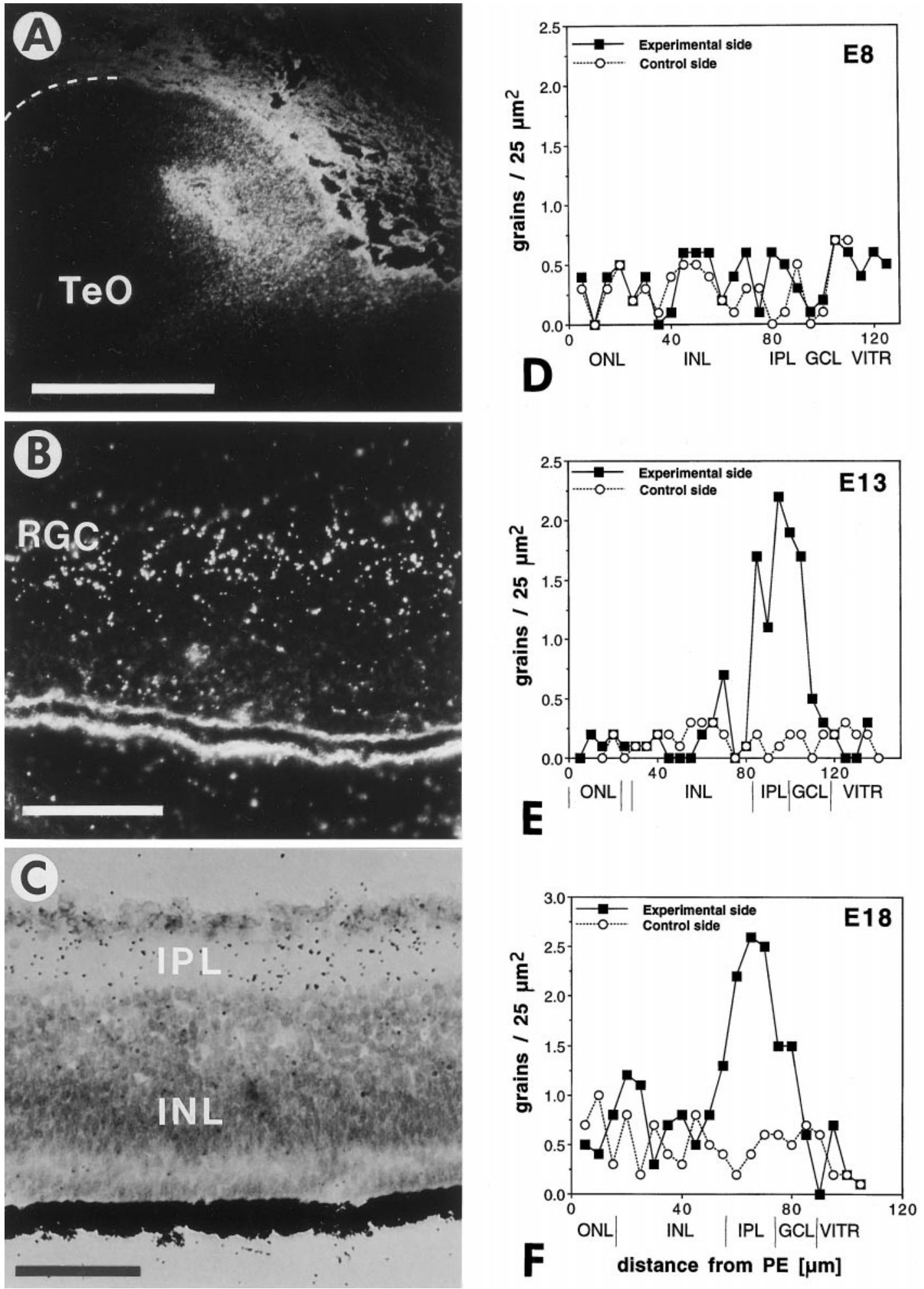

Figure 8. Retrograde transport of exogenous ${ }^{125}$ I-labeled BDNF from the tectum to the retina. $A$, Dark-field view of an injection site in the tectum (TeO) of an 18-d-old (E18) chick embryo. The surface of the tectum is indicated with a dashed line. Dorsal is to the top, and lateral is to the left. Scale bar, 1 $\mathrm{mm} . B$, Dark-field view of the contralateral retina of the same animal showing increased grain density over the inner nuclear layer and the ganglion cell layer, which comprises mostly retinal ganglion cells $(R G C)$. Scale bar, $50 \mu \mathrm{m}$. $C$, Bright-field view of the contralateral retina of an E13 embryo showing increased grain densities $\left({ }^{125} \mathrm{I}-\mathrm{BDNF}\right)$ in the ganglion cell layer and inner plexiform layer (IPL) after injection into the tectum. The outer nuclear layer $(\mathrm{ONL})$ is not labeled. $D-F$, Grain density profiles of $\mathrm{I}^{125}$-BDNF label in the retinae after unilateral injections into the tectum of E8 $(D)$, E13 $(E)$, and E18 $(F)$ embryos. The filled squares represent averages from 10 traces through the contralateral retina; the open circles represent averages from 10 traces through the ipsilateral (control) retina (background). The retinal layers and the distances from the pigment epithelium $(P E)$ are indicated at the bottom. $O N L$, Outer nuclear layer; $I N L$, inner nuclear layer; $I P L$, inner plexiform layer; GCL, ganglion cell layer; VITR, vitreous body. Note that iodinated BDNF accumulates in the retina at E13 and E18, but not at E8, and that most of the radioactivity accumulates in the IPL layer; a smaller amount is present in the GCL, which contains the retinal ganglion cell bodies. 

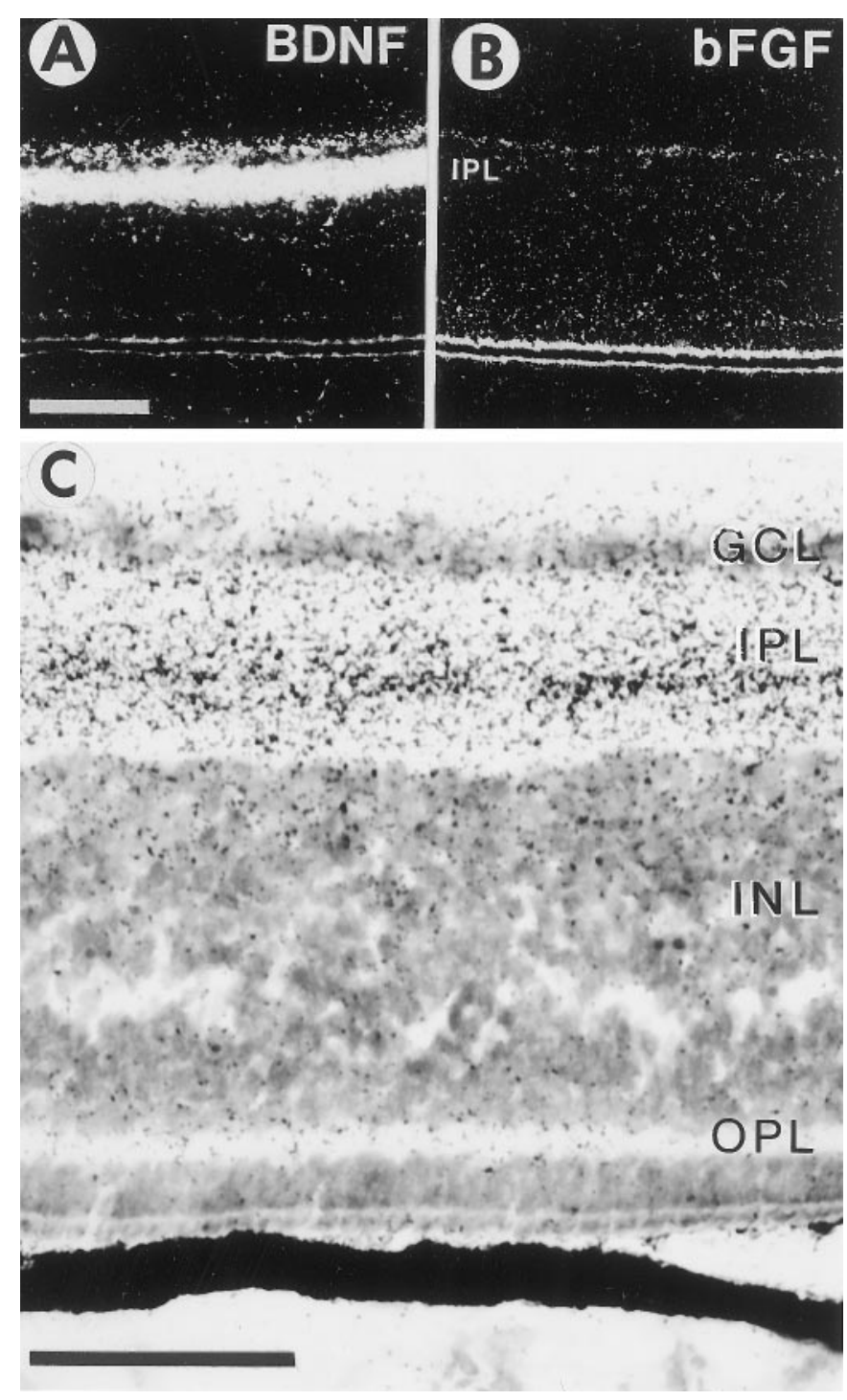

Figure 9. Accumulation of radio-iodinated $\operatorname{BDNF}(A, C)$ and basic fibroblast growth factor $(b F G F, B)$ in the retina after intraocular injection. $A$, Dark-field view of an autoradiographic section through the E16 retina after the injection of $\sim 10 \mathrm{ng}$ of iodinated BDNF in the eye. Scale bar, $100 \mu \mathrm{m}$. $B$, Dark-field view of an autoradiographic section through the E16 retina after the injection of $\sim 10 \mathrm{ng}$ of bFGF. Note that bFGF does not accumulate significantly in any retinal layer. $C$, Bright-field view at a higher magnification of the same retina shown in $A$. Note that BDNF accumulates differentially in the retinal layers, with the highest grain densities in the central part of the inner plexiform layer (IPL), with moderate densities in the ganglion cell layer $(G C L)$ and the inner border of the inner nuclear layer (INL), and with low densities in the outer plexiform layer $(O P L)$. Scale bar, $50 \mu \mathrm{m}$.

shown). The GCL was labeled with very low intensity. Because cells in the GCL express p75 mRNA at E15-E16 (von Bartheld et al., 1991) and the RGC axon terminals contain p75 receptor protein (von Bartheld, 1997), the RGC appear to export p75 receptors rapidly from the cell body to their dendrites in the IPL and to their axons in the optic tectum.

\section{Cross-linking and immunoprecipitation of BDNF to p75 and trkB receptors in the retina}

Neurotrophins have been cross-linked to $130-140 \mathrm{kDa}$ and 75 $\mathrm{kDa}$ receptors in the retina, presumably trk and p75 receptors, respectively (Escandón and Chao, 1990; Escandón et al., 1994;
Cohen-Cory et al., 1996). To determine which receptors contribute to the binding of BDNF, we injected ${ }^{125}$ I-labeled BDNF into the retina, cross-linked it $20 \mathrm{hr}$ later with EDC or DSS to its receptors, and immunoprecipitated it with antibodies specific for chicken p75, trkB, or trkC (courtesy of L. F. Reichardt, F. Lefcort, and D. O. Clary, Howard Hughes Medical Institute, University of California, San Francisco, CA). These experiments showed that a major fraction of the BDNF was bound to receptors $(\sim 20-25 \%)$. The large majority of the receptor-bound fraction was immunoprecipitated with the $\mathrm{p} 75$ antibody, whereas a minor fraction was precipitated with the trkB antibody (Fig. 10B). These data suggest that most of the receptor-bound BDNF was associated with p75.

A small amount of BDNF was immunoprecipitated consistently with trkC antibodies in retinal tissues, but not in the optic nerve or the isthmo-optic nucleus after axonal transport (von Bartheld, 1996). These data indicate that some of the injected BDNF binds to trkC, consistent with the report that, at 100- to 500-fold increased levels, BDNF effectively binds to trkC and phosphorylates it (Ip et al., 1993). The retinal concentration of BDNF after injection was $\sim 100-500$ times higher (total BDNF $=$ 5-10 ng) than the concentration of endogenous BDNF at this age (total BDNF/retina $\approx 50$ pg) (Johnson et al., 1996; J. E. Johnson, Wake Forest University, personal communication). Alternative explanations of BDNF immunoprecipitation with trkC antibodies include the possibilities that heterodimers of exogenous BDNF and endogenous NT-3 form that bind to trkC (Jungbluth et al., 1994; Philo et al., 1994), that trk and p75 may coprecipitate (Huber and Chao, 1995), or that the trkC antibody may recognize certain isoforms of trkB (Garner et al., 1996) although it does not recognize the predominant form of trkB (Lefcort et al., 1996).

When the immunoprecipitation was performed without previous cross-linking, there was a three- to fourfold increase in nonspecific binding and a shift in the ratio with which the p75 and trkB antibodies precipitated the ${ }^{125}$ I-labeled BDNF. p75 antibodies precipitated only $39.7 \pm 12.9 \%$ (SEM; $n=6)$ of the receptorbound BDNF, whereas trkB antibodies precipitated $60.3 \pm 12.9 \%$ (SEM; $n=6$ ) of the receptor-bound BDNF. With cross-linkers the ratio was reversed to approximately 60:30 (p75:trkB; Fig. $10 B)$. These data indicate that BDNF dissociates from the $\mathrm{p} 75$ receptor (but not from trkB) unless it is cross-linked, and the data provide circumstantial evidence for the relative efficiency of the cross-linkers. The increased pool of dissociated BDNF may account for the higher nonspecific binding observed without the cross-linkers.

To determine whether the efficiencies of immunoprecipitation were approximately similar between the p75 and the trkB antibodies, we analyzed Western blots and compared the relative amount of precipitated p75 or trkB. Labeled bands at $\approx 75$ and $\approx 140 \mathrm{kDa}$ from pellets and supernatants were taken to be $\mathrm{p} 75$ and trkB, respectively. When they were precipitated with trkB or p75 antibodies, the density ratios between the pellets and supernatants were $2.46 \pm 0.38$ (SEM) and $2.26 \pm 0.14$ (SEM) for trkB and $\mathrm{p} 75$, respectively. When they were precipitated with control $\mathrm{IgG}$, the densities were similar in the pellets and supernatants (ratio of $1.12 \pm 0.37$; SEM). These data indicate that the efficiencies of the p75 and trkB antibodies were approximately similar (Fig. 10C). In conclusion, most of the receptor-bound exogenous BDNF in the retina binds to $\mathrm{p} 75$ receptors present in the IPL, whereas a minor fraction of BDNF binds to trkB receptors. The distribution of $\mathrm{p} 75$ in the IPL is consistent with the notion that most of the exoge- 

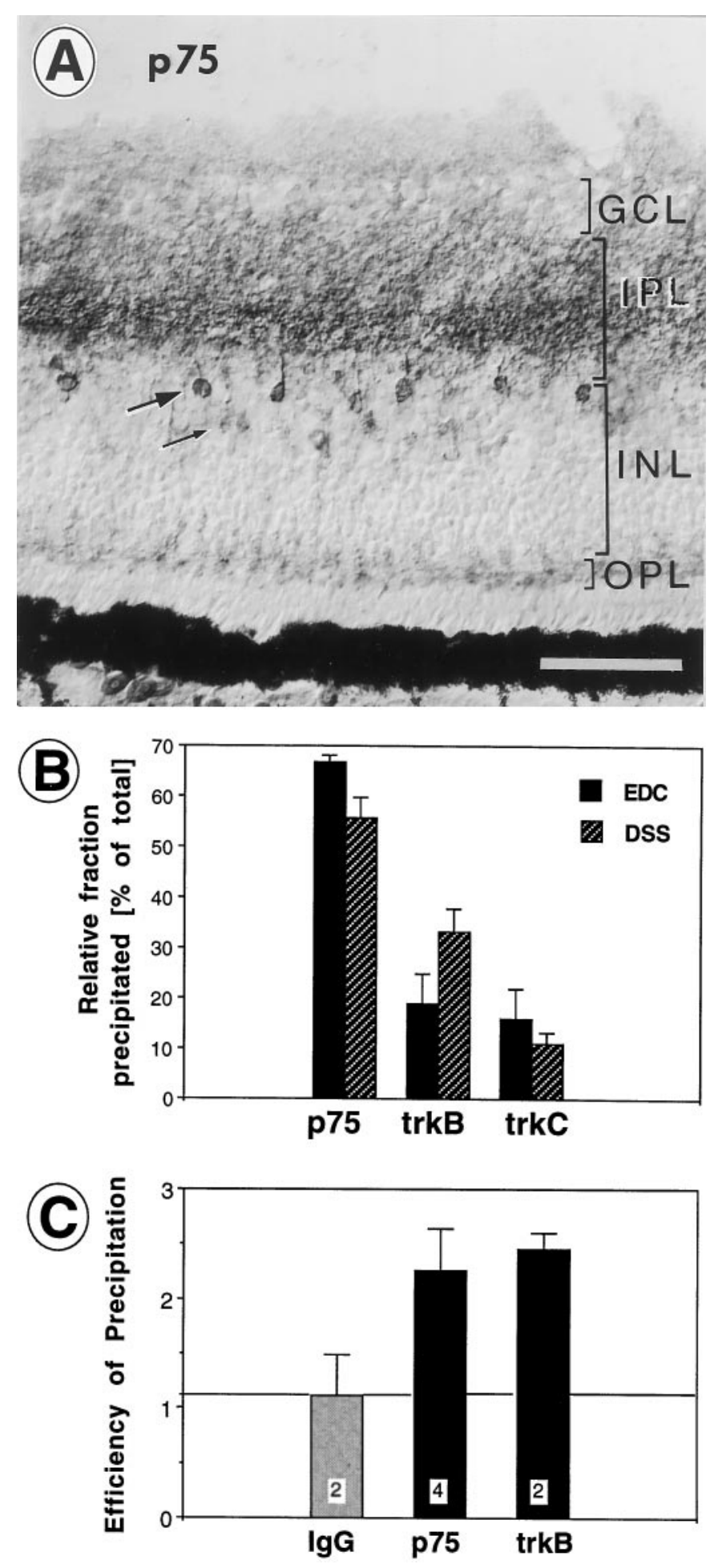

Figure 10. A, Distribution of p75 receptor immunoreactivity in the central retina of a 16-d-old chick embryo. Note the heavy labeling in the central parts of the inner plexiform layer (IPL) and heavily labeled cell bodies and processes of presumptive amacrine cells in the inner margin of the inner nuclear layer (INL, large arrow). Faintly labeled cell bodies are located in the center of the INL (thin arrow). Light labeling is present in the ganglion cell layer $(G C L)$ and in the outer plexiform layer $(O P L)$. Endogenous p75 is abundant in layers in which exogenous BDNF accumulates (see Fig. $9 C$ ). Scale bar, $50 \mu \mathrm{m}$. B, Relative contributions of p75, trkB, and trkC to the fraction of BDNF that was bound to receptors and could be immunoprecipitated with antibodies after cross-linking with EDC or DSS. Averages of four to seven independent experiments. Note nous BDNF that accumulates in the retina binds to $\mathrm{p} 75$ rather than to full-length trkB receptors.

\section{Contributions of the tectum and retina as sources of BDNF for RGC}

To distinguish between the two sources of BDNF for RGC and to determine their contributions to the accumulation of BDNF within RGC neurons in the retina, we compared the distribution and intensity of BDNF immunoreactivity in E8.5 retinae after optic stalk transection (at E4) with those in normal retinae. In addition, these experiments provided information as to whether the relative paucity of BDNF protein in the tectum was attributable to the rapid depletion by retrograde transport to RGC neurons; if this were the case, one would expect to see increased BDNF immunolabel in the tectum when BDNF transport to RGC is prevented. No difference could be observed in either the disconnected tectum or the GCL lacking target innervation (see Figs. $6 C, 5 A$ ), indicating that most of the BDNF-immunoreactive material in RGC was not derived from the tectum. Furthermore, newly generated neurons in the GCL close to the ora serrata were immunolabeled (see Fig. 6A). At this stage these neurons presumably do not yet have axons or growth cones that have reached the tectum (Rager, 1980) and therefore do not have access to the target and could not have taken up and retrogradely transported BDNF from the tectum. These data indicate that the majority of BDNF labeled with the antiserum in RGC is derived from retinal sources rather than from the tectum.

\section{DISCUSSION}

The objectives of this study were to localize BDNF transcripts and protein in the tectum and retina and to determine the contributions of local cells and target cells as sources of BDNF for RGC. Our main claim is that the majority of the BDNF in RGC neurons is derived from local retinal sources, presumably amacrine cells and/or bipolar cells. Although target cells in the optic tectum express BDNF and BDNF is transported retrogradely from the tectum to the RGC, the target-derived $\mathrm{BDNF}$ is only a minor fraction of the total BDNF in RGC. These findings have implications for the neurotrophic hypothesis of targetderived factors and raise intriguing questions about differences in trophic functions of neurotrophins, depending on whether they are internalized at the axon terminal or by dendritic processes.

\section{BDNF as a target-derived trophic factor}

Previous studies have shown that RGC depend on their target during development. Preventing target encounter by ablation of the optic tectum or by optic stalk transection significantly increases normal developmental cell death of RGC (Hughes and LaVelle, 1975; Vanselow et al., 1990), and coculturing RGC with the tectum increases survival of RGC in vitro (Nurcombe and

$\leftarrow$

that the majority of receptor-bound BDNF binds to p75. Error bars indicate SEM. $C$, Relative efficiencies of the antibodies for immunoprecipitation of p75 and trkB. Samples of the immunoprecipitates (pellets) and supernatants were Western-blotted (6\% SDS gel) and visualized with secondary horseradish peroxidase chemoluminescence or ${ }^{125}$ I-labeled p75 or trkB antibodies. The resulting bands at $75 \mathrm{kDa}(p 75)$ and $140 \mathrm{kDa}$ $(\operatorname{trk} B)$, respectively, were quantified by densitometry, and the ratios of density values (pellet/supernatant) were compared. Irrelevant antiserum $(\operatorname{Ig} G)$ did not immunoprecipitate the antigen, whereas the p75 and trkB antibodies showed approximately equal efficiencies for immunoprecipitation (average ratios of 2.2. and 2.5). Error bars indicate SEM. The number of independent experiments is indicated within white squares. 
Bennett, 1981). BDNF promotes the survival of RGC in vitro (Johnson et al., 1986; Rodríguez-Tébar et al., 1989; Thanos et al., 1989; Cohen-Cory and Fraser, 1994) and in vivo (Mey and Thanos, 1993; Mansour-Robaey et al., 1994; Unoki and LaVail, 1995; Weibel et al., 1995) [Voci et al. (1993), as cited in Garner et al. (1996)]. BDNF has been suggested to be a trophic factor derived from the tectum, and expression of BDNF mRNA in the tectum of several different species supports this hypothesis (Leibrock et al., 1989; Cohen-Cory and Fraser, 1994; Herzog et al., 1994). Attempts to demonstrate retrograde transport of NGF in this system failed (Yip and Johnson, 1983; Carmignoto et al., 1989), although BDNF is transported from the tectum to the retina in adult rat (Fournier et al., 1997). Our data show that neurons of the retinorecipient layers of the optic tectum express $\mathrm{BDNF}$, and we demonstrate, for the first time, that exogenously applied BDNF is transported from the tectum to the retina in the developing animal. These findings are consistent with the proposed role of BDNF as a target-derived trophic factor for RGC. RGC axons respond to BDNF in the tectum by sprouting and arborization (Cohen-Cory and Fraser, 1995). Thus, the role of $\mathrm{BDNF}$ as a target-derived trophic molecule for RGC is well established. Surprisingly, however, our data indicate that most of the BDNF in the RGC is not derived from the tectum, but comes from the retina itself.

\section{BDNF as an afferent trophic factor}

Developing neurons are supported not only by trophic signals derived from their target but also from their afferent inputs (Kelly and Cowan, 1972; Oppenheim, 1991; Linden, 1994). Although several target-derived trophic factors have been identified that are transported retrogradely by their axons from the target to the cell bodies, less is known about the trophic signals provided by afferents or paracrine factors. Afferents are thought to have comparable trophic effects on developing neurons as the target (Linden, 1994). Could BDNF be this or one of these trophic factors? In the chick retina, most of the BDNF-like immunoreactivity was found in the GCL. RGC lacking their target showed a similar labeling intensity when compared with control retinae, indicating that BDNF in the RGC is not attributable to accumulation derived from the tectum. During naturally occurring cell death, BDNF transcripts are located primarily in the outer half of the INL, which contains the cell bodies of horizontal, bipolar, and Müller cells. Based on the in situ hybridization of sections in which RGC were identified by retrograde tracing, $<3 \%$ of ganglion cells express BDNF mRNA. Quantitative RT-PCR of the BDNF mRNA levels in retinae with and without this cell population confirmed this conclusion. Although some BDNF may be produced by $\mathrm{RGC}$, the main portion of $\mathrm{BDNF}$ in the retina is expressed by cells other than RGC. Besides a subpopulation $(\approx 15 \%)$ of amacrine cells in the GCL, these cells presumably are horizontal and/or bipolar cells or Müller glia. BDNF produced by these cells seems to accumulate in RGC, presumably after anterograde (afferent) transport, release, and uptake by RGC dendrites in the IPL. Anterograde transport of endogenous (Zhou and Rush, 1996) and exogenous neurotrophins (von Bartheld et al., 1996a; Johnson et al., 1997) has been demonstrated recently. The work of Linden and collaborators (de Araujo and Linden, 1993; Linden, 1994; AryPires et al., 1997) has shown that RGC respond to trophic factors obtained from cells within the retina. RGC dendrites are thought to compete for such a trophic factor during development (Perry and Linden, 1982; Linden, 1994). When we injected iodinated BDNF into the eye, it accumulated in the IPL and the GCL, supporting the view that RGC can accumulate BDNF from their surrounding tissue. The IPL showed the most intense binding of exogenously applied BDNF, indicating that this neuropil contains the vast majority of BDNF binding sites in the retina. Both p75 and trkB receptor mRNAs are expressed by cells within the GCL and at the inner border of the INL (von Bartheld et al., 1991; Garner et al., 1996; Hallböök et al., 1996). These data are consistent with the notion that amacrine and/or bipolar cells express BDNF, which is transported anterogradely to the afferent terminals, released, taken up by the dendrites of RGC, and transported to their cell bodies.

\section{What is the function of BDNF in the visual system?}

In addition to its established survival functions in vitro (Johnson et al., 1986; Rodríguez-Tébar et al., 1989; Cohen-Cory and Fraser, 1994), BDNF increases in vivo the survival of injured RGC in birds [Voci et al. (1993), as cited in Garner et al. (1996)] and in mammals (Mey and Thanos, 1993; Mansour-Robaey et al., 1994; Weibel et al., 1995). BDNF also regulates the branching of developing axons in the tectum (Cohen-Cory and Fraser, 1995) and cortex (Cabelli et al., 1995) and the branching of dendritic processes of cortical neurons in vitro (McAllister et al., 1995, 1996). Another likely role of BDNF in the chick retina is to act as a trophic factor for isthmo-optic neurons. Of this neuronal population, $60 \%$ is eliminated during naturally occurring cell death (Clarke and Cowan, 1976; Clarke, 1992). Cell death of a significant number of isthmo-optic neurons can be delayed or prevented by intraocular BDNF (von Bartheld et al., 1994; Primi and Clarke, 1996). Expression of BDNF in the retina, therefore, may serve to support these neurons.

The role of BDNF as a physiological survival factor for normal RGC in vivo is less clear. Application of BDNF reduced the normal developmental RGC death in hamsters (Frost et al., 1997), but not in chick embryos (Cellerino et al., 1995; Drum et al., 1996). The number of cells in the ganglion cell layer was not visibly reduced in BDNF -/- mice (Jones et al., 1994), although RGC axons were hypomyelinated in these animals (Cellerino et al., 1997). The most parsimonious explanation could be that other factors are responsible or can compensate to support the survival of RGC. Double knock-out experiments with BDNF/NT-4 have been performed, but RGC survival was not analyzed (Liu et al., 1995). Another possibility is that BDNF may not transduce the same signal when it binds to receptors at the RGC dendrite and at the RGC axon terminal. The presumptive signal-transducing receptor is trkB (Barbacid, 1994). RGC express trkB mRNA and protein (Garner et al., 1996; Hallböök et al., 1996; von Bartheld et al., 1996a), but immunolabel for the trkB kinase was restricted to the GCL (Okazawa et al., 1995; Cellerino and Kohler, 1997), with no label in the IPL, which contains the RGC dendrites. The large majority of exogenously introduced BDNF accumulates in the IPL, and most of the BDNF, which is receptor-bound in the retina, binds to $\mathrm{p} 75$. Thus, although our study shows that the amount of BDNF within RGC that is derived from the retina is much larger than that derived from the tectum, target-derived retrogradely transported BDNF may be more effective in promoting RGC survival than BDNF binding to p75 expressed on RGC dendrites. Such mechanisms may be responsible for the high concentration of BDNF necessary to rescue relatively modest numbers of injured RGC axons from cell death (MansourRobaey et al., 1994) and may limit the efficiency of this neurotrophin after intraocular delivery in promoting RGC survival.

Taken together, our studies indicate that BDNF can accumu- 
late in RGC through axons but also through dendrites. Whether injected BDNF acts on axotomized RGC via uptake by dendrites or the axonal stumps is not known. Further studies are needed to investigate whether there might be different roles for BDNF as a target-derived factor and as an afferent-derived factor. These studies will have implications for the treatment of degenerating RGC after optic nerve lesions.

Note added in proof. While this paper was reviewed, BDNF was immunolocalized in the developing chick retina [Das I, Hempstead BL, Macleish PR, Sparrow JR (1997) Immunohistochemical analysis of the neurotrophins BDNF and NT-3 and their receptors trkB, trkC and $\mathrm{p} 75$ in the developing chick retina, Vis Neurosci 14:835-842]. The BDNF localization is consistent with our data.

\section{REFERENCES}

Acheson A, Conover JC, Fandl JP, DeChiara TM, Russell M, Thadani A, Squinto SP, Yancopoulos GD, Lindsay RM (1995) A BDNF autocrine loop in adult sensory neurons prevents cell death. Nature 374:450-453.

AryPires R, Nakatani M, Rehen SK, Linden R (1997) Developmentally regulated release of intraretinal neurotrophic factors in vitro. Int J Dev Neurosci 15:239-255.

Auerbach R, Kubal L, Folkman J (1974) A simple procedure for the long-term cultivation of chick embryos. Dev Biol 41:391-394.

Ballarin M, Ernfors N, Persson H (1991) Hippocampal damage and kainic acid injection induce a rapid increase in mRNA for BDNF and NGF in the rat brain. Exp Neurol 114:35-43.

Barbacid M (1994) The Trk family of neurotrophin receptors. J Neurobiol 25:1386-1403.

Bothwell M (1995) Functional interactions of neurotrophins and neurotrophin receptors. Annu Rev Neurosci 18:223-253.

Cabelli RJ, Hohn A, Shatz CJ (1995) Inhibition of ocular dominance column formation by infusion of NT-4/5 or BDNF. Science 267:1662-1666.

Carmignoto G, Maffei L, Candeo P, Canella R, Comelli C (1989) Effect of NGF on the survival of rat retinal ganglion cells following optic nerve section. J Neurosci 9:1263-1272.

Castrén E, Zafra F, Thoenen H, Lindholm D (1992) Light regulates expression of brain-derived neurotrophic factor mRNA in rat visual cortex. Proc Natl Acad Sci USA 89:9444-9448.

Cellerino A, Kohler K (1997) Brain-derived neurotrophic factor/ neurotrophin-4 receptor trkB is localized on ganglion cells and dopaminergic amacrine cells in the vertebrate retina. J Comp Neurol 386:149-160.

Cellerino A, Strohmaier C, Barde Y-A (1995) Brain-derived neurotrophic factor and the developing chick retina. In: Life and death in the nervous system (Ibáñez CF, ed), pp 131-139. Oxford: Elsevier.

Cellerino A, Carroll P, Thoenen H, Barde Y-A (1997) Reduced size of retinal ganglion cell axons and hypomyelination in mice lacking brainderived neurotrophic factor. Mol Cell Neurosci 9:397-408.

Clarke PGH (1985) Neuronal death during development in the isthmooptic nucleus of the chick: sustaining role of afferents from the tectum. J Comp Neurol 234:365-379.

Clarke PGH (1992) Neuron death in the developing avian isthmo-optic nucleus, and its relation to the establishment of functional circuitry. J Neurobiol 23:1140-1158.

Clarke PGH, Cowan WM (1976) The development of the isthmo-optic tract in the chick, with special reference to the occurrence and correction of developmental errors in the location and connections of isthmooptic neurons. J Comp Neurol 167:143-163.

Cohen-Cory S, Fraser SE (1994) BDNF in the development of the visual system of Xenopus. Neuron 12:747-761.

Cohen-Cory S, Fraser SE (1995) Effects of brain-derived neurotrophic factor on optic axon branching and remodeling in vivo. Nature 378:192-196.

Cohen-Cory S, Escandón E, Fraser SE (1996) The cellular patterns of $\mathrm{BDNF}$ and trkB expression suggest multiple roles for BDNF during Xenopus visual system development. Dev Biol 179:102-115.

Crossland WJ, Cowan WM, Rogers LA (1975) Studies on the development of the chick optic tectum. IV. An autoradiographic study of the development of retinotectal connections. Brain Res 91:1-23.

de Araujo EG, Linden R (1993) Trophic factors produced by retinal cells increase the survival of retinal ganglion cells in vitro. Eur J Neurosci 5:1181-1188.

Drum K, Forbes ME, Wang SW, Johnson JE (1996) Treatment with BDNF does not prevent normal chick retinal ganglion cell death in ovo. Soc Neurosci Abstr 22:998.

Ehrlich D (1981) Regional specialization of the chick retina as revealed by the size and density of neurons in the ganglion cell layer. J Comp Neurol 195:643-657.

Escandón E, Chao MV (1990) Identification of high- and low-affinity NGF receptors during development of the chicken central nervous system. Dev Biol 142:293-300.

Escandón E, Soppet D, Rosenthal A, Mendoza-Ramirez J-L, Szönyi É, Burton LE, Henderson CE, Parada LF, Nikolics K (1994) Regulation of neurotrophin receptor expression during embryonic and postnatal development. J Neurosci 14:2054-2068.

Fournier AE, Beer J, Arregui CO, Essagian C, Aguayo AJ, McKerracher L (1997) Brain-derived neurotrophic factor modulates GAP-43 but not T-alpha-1 expression in injured retinal ganglion cells of adult rats. J Neurosci Res 47:561-572.

Fritzsch B, Hallböök F (1996) A simple and reliable technique to combine oligonucleotide probe in situ hybridization with neuronal tract tracing in vertebrate embryos. Biotech Histochem 71:289-294.

Frost DO, MA Y-T, Hsieh T, Forbes ME, Yan Q, Johnson JE (1997) BDNF injected into retinal targets reduces developmental ganglion cell death. Soc Neurosci Abstr 23:615.

Gao H, Qiao X, Hefti F, Hollyfield JG, Knusel B (1997) Elevated mRNA expression of brain-derived neurotrophic factor in retinal ganglion cell layer after optic nerve injury. Invest Ophthalmol Vis Sci 38:1840-1847.

Garner AS, Menegay HJ, Boeshore KL, Xie XY, Voci JM, Johnson JE, Large TH (1996) Expression of trkB receptor isoforms in the developing avian visual system. J Neurosci 16:1740-1752.

Hallböök F, Ibáñez CF, Ebendal T, Persson H (1993) Cellular localization of brain-derived neurotrophic factor and neurotrophin-3 mRNA expression in the early chicken embryo. Eur J Neurosci 5:1-14.

Hallböök F, Bäckström A, Kullander K, Ebendal T, Carri NG (1996) Expression of neurotrophins and trk receptors in the avian retina. J Comp Neurol 364:664-676.

Hamburger V, Hamilton H (1951) A series of normal stages in the development of the chick embryo. J Morphol 88:49-92.

Hardy O, Leresche N, Jassik-Gerschenfeld D (1985) Morphology and laminar distribution of electrophysiologically identified cells in the pigeon optic tectum: an intracellular study. J Comp Neurol 233:390-404.

Harlow E, Lane D (1988) Antibodies. A laboratory manual. Cold Spring Harbor, NY: Cold Spring Harbor Laboratory.

Herzog KH, Barde YA (1994) BDNF mRNA levels in the chick optic tectum are regulated by neurotransmitters during synaptogenesis. Soc Neurosci Abstr 20:1304.

Herzog KH, Bailey K, Barde YA (1994) Expression of the BDNF gene in the developing visual system of the chick. Development 120:1643-1649.

Hockfield S, Carlson S, Evans C, Levitt P, Pintar J, Silberstein L (1993) Selected methods for antibody and nucleic acid probes. Molecular probes of the nervous system, Vol 1. Cold Spring Harbor, NY: Cold Spring Harbor Laboratory.

Huber LJ, Chao MV (1995) A potential interaction of p75 and trkA NGF receptors revealed by affinity crosslinking and immunoprecipitation. J Neurosci Res 40:557-563.

Hughes WF, LaVelle A (1975) The effects of early tectal lesions on development in the retinal ganglion cell layer of chick embryos. J Comp Neurol 163:265-283.

Hughes WF, McLoon (1979) Ganglion cell death during normal retinal development in the chick: comparison with cell death induced by early target field destruction. Exp Neurol 66:587-601.

Hunt SP, Brecha N (1984) The avian optic tectum: a synthesis of morphology and biochemistry. In: Comparative neurology of the optic tectum (Vanegas H, ed), pp 619-648. New York: Plenum.

Ip NY, Stitt TN, Tapley P, Klein R, Glass DJ, Fandl J, Greene LA, Barbacid M, Yancopoulos GD (1993) Similarities and differences in the way neurotrophins interact with the trk receptors in neuronal and nonneuronal cells. Neuron 10:137-149.

Johnson F, Hohmann SE, DiStefano PS, Bottjer SW (1997) Neurotrophins suppress apoptosis induced by deafferentation of an avian motorcortical region. J Neurosci 17:2101-2111. 
Johnson JE, Barde YA, Schwab ME, Thoenen H (1986) Brain-derived neurotrophic factor supports the survival of cultured rat retinal ganglion cells. J Neurosci 6:3031-3038.

Johnson JE, Forbes ME, Drum K, Anstrom J (1996) Measurements of BDNF protein during CNS development. Soc Neurosci Abstr 22:295.

Jones KR, Farinas I, Backus C, Reichardt LF (1994) Targeted disruption of the BDNF gene perturbs brain and sensory neuron development but not motor neuron development. Cell 76:989999.

Jungbluth S, Bailey K, Barde YA (1994) Purification and characterization of a brain-derived neurotrophic factor/neurotrophin-3 (BDNF/ NT-3) heterodimer. Eur J Biochem 221:677-685.

Kelly JP, Cowan MW (1972) Studies on the development of the chick optic tectum. III. Effects of early eye removal. Brain Res 42:263-288.

Kuenzel WJ, Masson M (1988) A stereotaxic atlas of the brain of the chick (Gallus domesticus). Baltimore: Johns Hopkins UP.

LaVail JH, Cowan WM (1971) The development of the chick optic tectum. I. Normal morphology and cytoarchitectonic development. Brain Res 28:391-419.

Layer PG, Vollmer G (1982) Lucifer yellow stains displaced amacrine cells of the chicken retina during embryonic development. Neurosci Lett 31:99-104.

Lefcort F, Clary DO, Rusoff A, Reichardt LF (1996) Inhibition of the NT-3 receptor trkC, early in chick neurogenesis, results in severe reductions in multiple neuronal subpopulations in the dorsal root ganglia. J Neurosci 16:3704-3713.

Leibrock J, Lottspeich F, Hohn A, Hofer M, Hengerer B, Masiakowski P, Thoenen H, Barde YA (1989) Molecular cloning and expression of brain-derived neurotrophic factor. Nature 341:149-152.

Linden R (1994) The survival of developing neurons: a review of afferent control. Neuroscience 58:671-682.

Liu X, Ernfors P, Wu H, Jaenisch R (1995) Sensory but not motor neuron deficits in mice lacking NT-4 and BDNF. Nature $375: 238-241$.

Maisonpierre PC, Belluscio L, Conover JC, Yancopoulos GD (1992) Gene sequence of chicken BDNF and NT-3. DNA Seq 3:49-54.

Mansour-Robaey S, Clarke DB, Wang YC, Bray GM, Aguayo AJ (1994) Effects of ocular injury and administration of brain-derived neurotrophic factor on survival and regrowth of axotomized retinal ganglion cells. Proc Natl Acad Sci USA 91:1632-1636.

McAllister AK, Lo DC, Katz LC (1995) Neurotrophins regulate dendritic growth in developing visual cortex. Neuron 15:791-803.

McAllister AK, Katz LC, Lo DC (1996) Neurotrophin regulation of cortical dendritic growth requires activity. Neuron 17:1057-1064.

Mey J, Thanos S (1993) Intravitreal injections of neurotrophic factors support the survival of axotomized retinal ganglion cells in adult rats in vivo. Brain Res 602:304-317.

Nawa H, Carnahan J, Gall C (1995) BDNF protein measured by a novel enzyme immunoassay in normal brain and after seizure: partial disagreement with mRNA levels. Eur J Neurosci 7:1527-1535.

Nurcombe V, Bennett MR (1981) Embryonic chick retinal ganglion cells identified in vitro. Their survival is dependent on a factor from the optic tectum. Exp Brain Res 44:249-258.

Okazawa H, Nishiyama K, Kamei M, Washizaki K, Murayama S, Kwak S, Kanazawa I (1993) Trk immunoreactivity at neuronal dendrite and cell body. Biochem Biophys Res Commun 194:683-690.

Okazawa H, Kamei M, Imafuku I, Kanazawa I (1995) Gene regulation of trkB and trkC in the chick retina by light/darkness exposure. Oncogene 9:1813-1818.

Oppenheim RW (1991) Cell death during development of the nervous system. Annu Rev Neurosci 14:453-501.

Ostrach LH, Mathers Jr LH (1979) Evidence for a critical period of neuronal trophism late in the development of the chick visual system. J Comp Neurol 183:415-428.

Page TP, Jaboro NG, Crossland WJ (1993) Retrograde transneuronal degeneration in a basal ganglia target, the lateral spiriform nucleus, induced by anterograde transneuronal degeneration following eye removal in the chicken. Exp Neurol 119:120-127.

Perez MT, Caminos E (1995) Expression of brain-derived neurotrophic factor and of its functional receptor in neonatal and adult rat retina. Neurosci Lett 183:96-99.

Perry VH, Linden R (1982) Evidence for dendritic competition in the developing retina. Nature 297:683-685.

Philo J, Talvenheimo J, Wen J, Rosenfeld R, Welcher A, Arakawa T (1994) Interactions of neurotrophin-3 (NT-3), brain-derived neurotro- phic factor (BDNF), and the NT-3.BDNF heterodimer with the extracellular domains of the TrkB and TrkC receptors. J Biol Chem 269:27840-27846.

Primi, MP, Clarke PGH (1996) Retrograde neurotrophin-mediated control of neurone survival in the developing central nervous system. NeuroReport 7:473-476.

Purves D (1988) Body and brain. A trophic theory of neural connections. Cambridge, MA: Harvard UP.

Rager GH (1980) Development of the retinotectal projection in the chicken. Adv Anat Embryol Cell Biol 63:1-92.

Rager G, Rager U (1978) Systems-matching by degeneration. Exp Brain Res 33:65-78.

Rager G, von Oeynhausen B (1979) Ingrowth and ramification of retinal fibers in the developing optic tectum of the chick embryo. Exp Brain Res 35:213-227.

Reiner A, Brecha N, Karten HJ (1979) A specific projection of retinal displaced ganglion cells to the nucleus of the basal optic root in the chicken. Neuroscience 4:1679-1688.

Repérant J, Angaut P (1977) The retinotectal projections in the pigeon. An experimental optical and electron microscope study. Neuroscience 2:119-140.

Rickman DW, Brecha NC (1995) Expression of the proto-oncogene, trk, receptors in the developing rat retina. Vis Neurosci 12:215-222.

Rodríguez-Tébar A, Jeffrey PL, Thoenen H, Barde Y-A (1989) The survival of chick retinal ganglion cells in response to brain-derived neurotrophic factor depends on their embryonic age. Dev Biol 136:296-303.

Rodríguez-Tébar A, Dechant G, Barde Y-A (1990) Binding of brainderived neurotrophic factor to the nerve growth factor receptor. Neuron 4:487-492.

Rosenfeld R, Philo JS, Haniu M, Stoney K, Rohde MF, Wu G-M, Narshi LO, Wong C, Boone T, Hawkins NN, Miller JM, Arakawa T (1993) Sites of iodination in recombinant human brain-derived neurotrophic factor and its effect on neurotrophic activity. Protein Sci 2:1664-1674.

Schoups AA, Elliott RC, Friedman WJ, Black IB (1995) NGF and BDNF are differentially modulated by visual experience in the developing geniculocortical pathway. Dev Brain Res 86:326-334.

Stöckel K, Guroff G, Schwab M, Thoenen H (1976) The significance of retrograde axonal transport for the accumulation of systemically administered nerve growth factor (NGF) in the rat superior cervical ganglion. Brain Res 109:271-284.

Tanaka H, Agata A, Obata K (1989) A new membrane antigen revealed by monoclonal antibodies is associated with motoneuron axonal pathways. Dev Biol 132:419-435.

Thanos S, Bonhoeffer F (1983) Investigations on the development and topographic order of retinotectal axons: anterograde and retrograde staining of axons and perikarya with rhodamine in vivo. J Comp Neurol 219:420-430.

Thanos S, Bähr M, Barde Y-A, Vanselow J (1989) Survival and axonal elongation of adult rat retinal ganglion cells: in vitro effects of lesioned sciatic nerve and brain-derived neurotrophic factor (BDNF). Eur J Neurosci 1:19-26.

Unoki K, LaVail MM (1995) Protection of the rat retina from ischemic injury by brain-derived neurotrophic factor, ciliary neurotrophic factor, and basic fibroblast growth factor. Invest Ophthalmol Vis Sci 35:907-915.

Vale RD, Shooter EM (1985) Assaying binding of nerve growth factor to cell surface receptors. Methods Enzymol 109:21-39.

Vanselow J, Dutting D, Thanos S (1990) Target dependence of chick retinal ganglion cells during embryogenesis: cell survival and dendritic development. J Comp Neurol 295:235-247.

Voci JM, McKeon RJ, Large TH (1993) Retroviral delivery of neurotrophin genes into the embryonic chick retina. Soc Neurosci Abstr 19:656.

von Bartheld CS (1996) Identification of the receptors which bind the neurotrophins BDNF and NT-3 during retrograde and anterograde axonal transport. Soc Neurosci Abstr 22:1002.

von Bartheld CS (1997) Anterograde transport of endogenous NT-3 from the retina to the optic tectum. Soc Neurosci Abstr 23:2244.

von Bartheld CS (1998a) Neurotrophins in the developing and regenerating visual system [invited review]. Histol Histopathol, in press.

von Bartheld CS (1998b) Tracing with radiolabeled neurotrophins. In: Neurotrophin and receptor methods and protocols (Rush RA, ed). Totowa, NJ: Humana, in press.

von Bartheld CS, Heuer JG, Bothwell M (1991) Expression of nerve 
growth factor (NGF) receptors in the brain and retina of chick embryos: comparison with cholinergic development. J Comp Neurol 310:103-129.

von Bartheld CS, Kinoshita Y, Prevette D, Yin QW, Oppenheim RW, Bothwell M (1994) Positive and negative effects of neurotrophins on the isthmo-optic nucleus of chick embryos. Neuron 12:639-654.

von Bartheld CS, Schober A, Kinoshita Y, Williams R, Ebendal T, Bothwell M (1995) Noradrenergic neurons in the locus coeruleus of birds express trkA, transport NGF, and respond to NGF. J Neurosci 15:2225-2239.

von Bartheld CS, Byers MR, Williams R, Bothwell M (1996a) Anterograde transport of neurotrophins and axodendritic transfer in the developing visual system. Nature 379:830-833.

von Bartheld CS, Williams R, Lefcort F, Clary DO, Reichardt LF, Bothwell M (1996b) Retrograde transport of neurotrophins from the eye to the brain in chick embryos: roles of the $\mathrm{p} 75^{\mathrm{NTR}}$ and $\operatorname{trkB}$ receptors. J Neurosci 16:2995-3008.
Weibel D, Kreutzberg GW, Schwab ME (1995) Brain-derived neurotrophic factor (BDNF) prevents lesion-induced axonal die-back in young rat optic nerve. Brain Res 679:249-254.

Weskamp G, Reichardt LF (1991) Evidence that biological activity of NGF is mediated through a novel subclass of high affinity receptors. Neuron 6:649-663.

Wizenmann A, Thanos S (1990) The developing chick isthmo-optic nucleus forms a transient efferent projection to the optic tectum. Neurosci Lett 113:241-246.

Yip HK, Johnson EM (1983) Retrograde transport of nerve growth factor in lesioned goldfish retinal ganglion cells. J Neurosci 3:2172-2182.

Zhou XF, Rush RA (1996) Endogenous brain-derived neurotrophic factor is anterogradely transported in primary sensory neurons. Neuroscience 74:945-951.

Zhou XF, Zettler C, Rush RA (1994) An improved procedure for the immunohistochemical localization of nerve growth factor-like immunoreactivity. J Neurosci Methods 54:95-102. 